\title{
Natural versus anthropogenic genesis of mardels (closed depressions) on the Gutland plateau (Luxembourg); archaeometrical and palynological evidence of Roman clay excavation from mardels
}

J. M. van Mourik ${ }^{1}$, D. J. G. Braekmans ${ }^{2,4}$, M. Doorenbosch ${ }^{2}$, W. J. Kuijper ${ }^{2}$, and J. van der Plicht ${ }^{2,3}$

${ }^{1}$ Institute for Biodiversity and Ecosystem Dynamics (IBED), University of Amsterdam, Science Park 904, Amsterdam, the Netherlands

${ }^{2}$ Faculty of Archaeology, University of Leiden, Einsteinweg 2, 2333CC Leiden, the Netherlands

${ }^{3}$ Centre for Isotope Research (CIO), University of Groningen, Nijenborgh 4, 9747AG Groningen, the Netherlands

${ }^{4}$ Materials Science and Engineering, Delft University of Technology, Mekelweg 2, 2628CD Delft, the Netherlands

\section{Natural versus anthropogenic genesis of mardels \\ on the Gutland \\ plateau}

J. M. van Mourik et al.

\section{Title Page}

Abstract

Introduction

Conclusions

References

Tables

Figures

14

4

Back

Close

\section{Full Screen / Esc}

Printer-friendly Version

Interactive Discussion 
Received: 14 November 2015 - Accepted: 4 December 2015 - Published: 15 January 2016

Correspondence to: J. M. van Mourik (j.m.vanmourik@uva.nl)

Published by Copernicus Publications on behalf of the European Geosciences Union.

SOILD

doi:10.5194/soil-2015-82

\section{Natural versus anthropogenic genesis of mardels on the Gutland plateau}

J. M. van Mourik et al.

Title Page

Abstract

Introduction

Conclusions

References

Tables

Figures

14

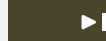

Back

Full Screen / Esc

Printer-friendly Version

Interactive Discussion 


\section{Abstract}

Mardels, small closed depressions, are distinctive landforms on the Luxembourger Gutland plateau. In the present landscape most mardels are shallow fens, filled with colluvial sediments. The genesis of mardels has been studied intensively, inside and out5 side Luxembourg. Some researchers suggested a natural development and consider mardels as subsidence basins due to subsurface solution of gypsum veins, other researchers suggested cultural causes and consider mardels as prehistorical quarries.

In the Gutland, mardels occur on various substrates. Mardels on the Strassen marls

$\left(\mathrm{li}^{3}\right)$ are abandoned quarries, related to clay excavation in Roman Time. Mardels on the

10 Luxembourger sandstone $\left(\mathrm{li}^{2}\right)$ are sinkholes, related to joint patterns in the sandstone formation. Mardels on the Keuper marls $\left(\mathrm{km}^{1,3}\right)$ are originally subsidence basins, related to subsurface dissolutions of gypsum lenses and veins, filled with colluvial clay. The results of pollen analysis and archaeometrical tests demonstrate Roman extraction of clay for the production of ancient ceramics. So, the natural depressions have been enlarged to the present mardels. After excavation, the sedimentation of colluvium restarted in the abandoned quarries.

\section{Introduction}

The geological structure (Fig. 1) of the Luxembourger Gutland is inherited from Tertiary and Quaternary landscape evolution, which was initiated by the Pliocene tectonic uplift of the entire region Luxembourg (Lucius, 1948). The present Gutland is a cuesta landscape, underlain by alternating tilted sedimentary rock formations with different resistance to weathering and erosion.

During the Pleistocene the landscape has been subjected to several cycles of weathering and erosion by the alternation of glacial and interglacial periods (Lucius, 1948;
SOILD

doi:10.5194/soil-2015-82

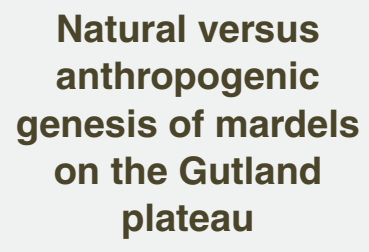

J. M. van Mourik et al.

\section{Title Page}

Abstract

Introduction

Conclusions

References

Tables

Figures

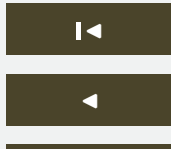

$\rightarrow 1$

Back

Close

\section{Full Screen / Esc}

Printer-friendly Version

Interactive Discussion 
sion and denudation under periglacial conditions. During interglacial periods, the landscape became vegetated, denudation was reduced and soil profiles could develop.

The Holocene landscape evolution started in a landscape with thin regolithic slope covers and Pre-Holocene gravelly deposits on the valley floors (Heuertz and Heyart, 5 1964; Verhoef, 1966). Plant growth, rock weathering and soil formation were the dominant processes in the Early Holocene (Slotboom and van Mourik, 2016).

Typically for the geomorphology of the Gutland plateau is the occurrence of mardels, small closed depressions. Mardels occur on various substrates, in particular on Lias and Keuper marls and may have different genesis (Fig. 2). In these mardels, fens and 10 wetlands developed which potentially contribute to the geodiversity and biodiversity of the present landscape. Peat and clayey mardels deposits are important soil archives for the paleoecological reconstruction of the Late Holocene landscape evolution (Slotboom and van Mourik, 2015).

The oldest descriptions of the mardels on the Luxembourger Gutland plateau were 15 done by Lucius $(1941,1948)$. He ascribed mardels, occurring on the Steinmergelkeuper $\left(\mathrm{km}^{3}\right)$ and the Pseudomorphosekeuper $\left(\mathrm{km}^{1}\right)$ to subsurface solution of calcareous or gypsum inclusions, followed by collapse and subsidence of the overlying beds. He postulated that mardels can also form by subsidence as a reaction on tectonic stress, causing joints in the Luxembourger sandstone formation.

Slotboom (1963) investigated 108 mardels on Gutland plateau on the Keuper marls. Based on his detailed field observations he confirmed the genetic conclusions of Lucius and considered mardels as natural phenomena.

Braque (1966) suggested that the mardels, observed on the plateau of Nivernais (France) are also geological phenomena that developed under periglacial conditions during the Late-Glacial and by karst processes during the Holocene.

Barth (1996) investigated mardels in Lorraine (France). Based on soil descriptions she confirmed the geological evolution of mardels in "Lorraine Gypsiferous Keuper" and rejected anthropogenic geneses. Also she postulated that the formation of mardels is still ongoing in the present landscape.
SOILD

doi:10.5194/soil-2015-82

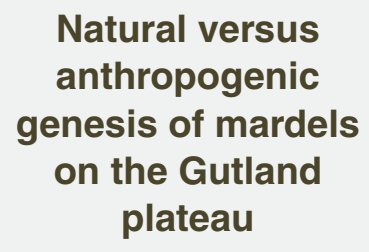

J. M. van Mourik et al.

\section{Title Page}

Abstract

Introduction

Conclusions

References

Tables

Figures

14

4

Back

Close

Full Screen / Esc

Printer-friendly Version

Interactive Discussion 
Thoen and Hérault (2006) investigated the development of CD's in forests in Lorraine. They suggested Holocene subsurface solution of evaporitic lenses of halite, gypsum and carbonate as the major process to explain the development of the CD's. They observed a range of depressions from mature to juvenile and concluded that the development of mardels is still going on.

The above cited researchers interpreted the mardels as the result of geological processes. Pollen diagrams of mardel fillings are produced of a selection of the Gutland mardels; the palynological age of the fillings is Post Roman, never older (Slotboom, 1963; Poeteray et al., 1984).

10 Schmalen (2002) made an actualized inventory of mardels on the Gutland plateau and also found mardels on the Lias formations $\left(\mathrm{Ii}^{3}\right.$ and $\left.\mathrm{Ii}^{2}\right)$. In these formations soluble inclusions are absent. For that reason she suggested an anthropogenic genesis of these mardels. However, her study focused on water quality and wetland species in these unique biotopes and without additional observations it is impossible to qualify 15 these mardels as natural or anthropogenic.

Etienne et al. (2011) considered anthropogenic factors as principal explanation for CD's in the Lorraine landscape. The sediments in the majority of these CD's could palynological be dated as Post Roman and consequently the majority of the depressions raised as Roman excavations with a Post Roman colluvial filling. They reported also the occurrence of some older and younger natural mardels, indicating that also in this region mardels could develop by subsurface dissolution of evaporitic lenses and soil subsidence. They postulate that in the present geomorphological context, genetically different CD's as periglacial pingos, sinkholes, subsidence basins and human excavations can have similar shapes. Therefore it is complicated to identify the correct genesis of such depressions.

Most of the mardels on the Gutland plateau occur in forests. It is assumed that outside the forest most mardels may have been masked out by agricultural levelling (Poeteray et al., 1984). Most mardels occur in clusters. On the $\mathrm{li}^{3}$ (Strassen Marls) examples of mardel clusters are found in the Scheiwelterboesch (eastern of Beaufort),
SOILD

doi:10.5194/soil-2015-82

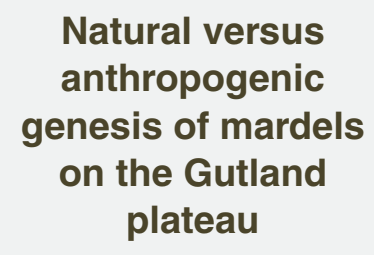

J. M. van Mourik et al.

\section{Title Page}

Abstract

Introduction

Conclusions

References

Tables

Figures

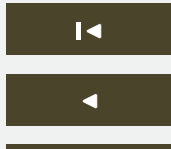

$\rightarrow 1$

Back

Close

\section{Full Screen / Esc}

Printer-friendly Version

Interactive Discussion 
the Laangebusch (soutwest of Berdorf) and in Oustert/Kalefeld, (east of Medernach). In the previous study by Poeteray at al. (1984) a pollen diagram of mardel Kalefeld was published (reproduced in Slotboom and van Mourik (2015), Fig. 10) and suggested a post Roman age of the filling, based on palynological time markers (e.g. Fagus and 5 Fagopyrum) and radiocarbon ages. The ${ }^{14} \mathrm{C}$ dates of Soil Organic Carbon (SOC), extracted from colluvium were not reliable due to the reservoir effect and overestimated the real age. The authors did not provide information about the genesis of the mardel, natural or anthropogenic. Therefore, Slotboom and Van Mourik (2015, Figs. 6 and 8) investigated the colluvial profiles of two mardels on the $\mathrm{li}^{3}$ near Berdorf and Beaufort. 10 Based on the pollen curves (e.g. Fagus and Fagopyrum and aquatics) and reliable radiocarbon dates of a thin basic layer, deposited on the bottom of the quarry ( $\approx$ AD 260) the mardel filling could be interpreted as post Roman. The CD's came into being after the excavation of clay and deeply weathered Strassen marls. It is a probability that Romans used local dug clay to produce their ceramics, which is supported by the finds of Roman pottery close to Kalefeld (Schmidt, 1995). After clay excavation, clayey colluvium has been deposited during the Subatlantic on completely truncated palaeosols (Slotboom and van Mourik, 2015).

On the $\mathrm{li}^{2}$ (Luxembourger Sandstone) elongated mardels in sink holes occur in linear clusters, related to faults and joints in the sandstone formation (Slotboom and van Mourik, 2015). Good examples are found in the Esselbur (western of Beaufort). Slotboom and van Mourik (2015, Fig. 4) investigated the filling of mardel Eltesmuer. At first, this mardel was filled with sandy colluvium and after that, due to water stagnation, peat could accumulate. The palynological and radiocarbon age of the basic layer of the peat deposit is Subboreal ( $\approx 2500 \mathrm{BC}$ ), that means pre Roman.

25 On the $\mathrm{km}^{3}$ (Steinmergelkeuper) examples of mardel clusters are found in the $\mathrm{Ge}$ brannte Boesch and Brasert (western of Stegen) and the Bois Biischtert (eastern of Michelbrough). In the studies of Lucius (1948) and Slotboom (1963) they were interpreted as natural depressions, developed by soil subsidence after subsurface solution of gypsum veins. Gypsum veins and lenses are included in de Keuper marls, but these
SOILD

doi:10.5194/soil-2015-82

Natural versus anthropogenic genesis of mardels

on the Gutland

plateau

J. M. van Mourik et al.

\section{Title Page}

Abstract Introduction

Conclusions References

Tables Figures

14 4

Back

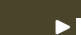

$>1$

Close

Full Screen / Esc

Printer-friendly Version

Interactive Discussion 
researchers do not present geological data to confirm the natural genesis and to exclude anthropogenic processes. Poeteray et al. (1984) published a pollen diagram of mardel Brasert (reproduced in Slotboom and van Mourik (2015), Fig. 12) and suggested, just as in mardel Kalefeld, a post Roman age of the filling, based on palyno5 logical time markers (e.g. Fagus and Fagopyrum) and radiocarbon ages.

The first aim of this study was to determine the natural versus anthropogenic genesis of the mardels on the Steinmergelkeuper. For this purpose we sampled the sediment of the mardels Medernach, Brasert2 (close the previously investigated Brasert mardel) and Michelbouch.

10 The second aim of this study was to answer the question if Romans extracted mardel for the production of ceramics. For this purpose we applied archaeometrical tests to match clay samples from mardels and soils with fragments of Roman pottery, found in the Bois Biischtert, close to the mardel Michelbouch (Jacobi, 2011).

\section{Materials and methods}

\subsection{Profile and sample selection}

The palynological references of the vegetation development will be based on the pollen diagram of the deposits in mardel Dauwelsmuer, a fen in a closed depression in the debris deposits of a landslide. Previously, Schwenninger (1989) published a rough pollen diagram (vertical resolution $15 \mathrm{~cm}$ ). We resampled the profile with a vertical resolution of $2.5 \mathrm{~cm}$. Also we sampled the fillings of the mardels Medernach, Brasert2 and Michelbouch on the Steinmergelkeuper, (vertical resolution $2.5 \mathrm{~cm}$ ) for pollen analysis. Additionally, we took samples from the mardel deposits and the soil beside the mardel for the grain size analysis and for the archaeometrical tests. Sample depth was $50-60 \mathrm{~cm}$.

25 Samples from soft sediments (peat and mardel clay) were taken with a peat sampler; samples from more resistant sediments (soil clay and weathered marls) were taken
SOILD

doi:10.5194/soil-2015-82

Natural versus anthropogenic genesis of mardels

on the Gutland

plateau

J. M. van Mourik et al.

\section{Title Page}

Abstract

Introduction

Conclusions

References

Tables

Figures

14

4

Back

Close

Full Screen / Esc

Printer-friendly Version

Interactive Discussion 
with an "Edelman" soil auger. The soil determination was based on the World Soil Resources Report 103 (Isric/Fao, 2006).

\subsection{Pollen extraction and pollen zonation}

Pollen extractions of the samples were carried out using the tufa extraction method (Moore et al., 1991). The exotic marker grain method was applied on the preparations for estimation of the pollen densities. For the identification of pollen grains the pollen key of Moore et al. (1991) was applied. The pollen extractions were performed in the Laboratory for Palynology of IBED, University of Amsterdam.

The pollen scores were calculated as percentages of the total pollen sum $10 \quad\left(200<\sum<400\right)$ of arboreal and herbal plant species. Curves of species with incidental scores were excluded from the pollen diagrams, the incidental scores of profile Dauwelsmuer are presented in Appendix A. A pollen density curve is added to the diagrams to show the discontinuity between deposits and the (truncated) palaeosols.

The geochronology of the diagrams presented in this paper is based on the palynological markers as recorded and on reliable radiocarbon dates in the profile of Dauwelsmuer. Some well dated palynological reflections of the vegetation and agricultural history can be observed, such as the transition of the Quercetum mixtum into the Fageto-Quercetum, the Subatlantic peaks of Fagus, the appearance of Fagopyrum and the appearance of Picea (Persch, 1950; Slotboom, 1963). The mardel sediments could 20 only palynologically be dated, not absolute because of the unreliability of radiocarbon dates. Organic matter, extracted from mardel deposits has been affected by reservoir effects (Mook and Streurman, 1983; Slotboom and van Mourik, 2015) and due to the input of inorganic carbon, supplied by the groundwater flow and of soil organic carbon, supplied by soil erosion the radiocarbon dates overestimate the real ages of the clayey
SOILD

doi:10.5194/soil-2015-82

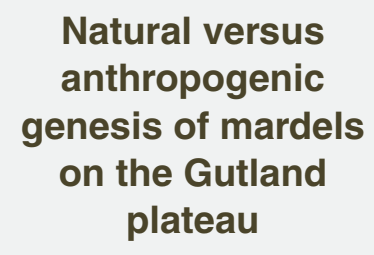

J. M. van Mourik et al.

\section{Title Page}

Abstract Introduction

Conclusions References

Tables Figures
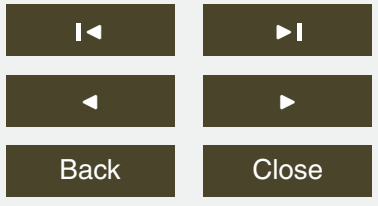

Back

Full Screen / Esc

Printer-friendly Version

Interactive Discussion 


\subsection{Analysis of macro remains}

From the Dauwelsmuer core the section has completely been analyzed for macro remains. The height of the examined samples was $2.5 \mathrm{~cm}$, a total of 93 samples between 0 and $232.5 \mathrm{~cm}$ below surface have been analyzed. Since the core was intended for 5 palynological research, a corer was used with a diameter of $2.5 \mathrm{~cm}$. As a consequence the samples for macro analysis remains were small and only a limited picture of local conditions regarding the vegetation (and fauna) was obtained. After cleaning and taking the pollen samples an average of $4 \mathrm{~cm}^{3}\left( \pm 1 \mathrm{~cm}^{3}\right)$ of material remained for the research of macro remains. After carefully sieving with tap water on a sieve with meshes of were identified, wood was identified in some occasions, the buds were not identified. The animal remains were assigned to a "group".

\subsection{Archaeometry}

Provenance analysis of ancient ceramic materials has been the scope of extensive 15 research over the past decennia. Many studies employ geochemical techniques in order to discriminate sources of ceramic production. It is generally accepted that clay raw materials utilized in the production of ceramic materials have a uniform chemical composition in which differences in ceramic chemistry reflect differences of the clay sources, and thus potential provenances (Hein et al., 2004; Braekmans et al., 2011; Degryse and Braekmans, 2014).

As an analytical technique, X-ray fluorescence analysis (XRF) has played a major role in sourcing ancient ceramics and determining the original clay resource. XRF utilizes the emission of characteristic "secondary" (or fluorescent) X-rays from a material that has been excited by bombarding with high-energy $\mathrm{X}$-rays. The emitted radiation for elemental analysis of solids, powders or liquids.

SOILD

doi:10.5194/soil-2015-82

\section{Natural versus anthropogenic genesis of mardels \\ on the Gutland \\ plateau}

J. M. van Mourik et al.

\section{Title Page}

Abstract Introduction

Conclusions References

Tables Figures

14

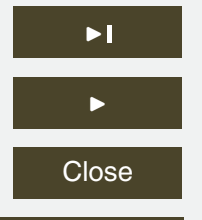

Back

Full Screen / Esc

Printer-friendly Version

Interactive Discussion 
In this study fourteen samples have been analyzed for their chemical composition: five soil samples, five mardel samples and four pieces of ceramics. All analyzed samples were powdered and oven dried at low temperature $\left(70^{\circ} \mathrm{C}\right)$ for at least $24 \mathrm{~h}$.

For XRF analysis the measurements were performed at the X-ray facilities of the 5 Materials Science and Engineering department, Delft University of Technology. The instrumentation used was a Panalytical Axios Max sequential wavelength dispersive $x$-ray fluorescence spectrometer (WD-XRF) and data evaluation was done with SuperQ5.0i/Omnian software. The system is equipped with an $\mathrm{Rh}$ anode featuring $4.0 \mathrm{~kW}$ operating power, $160 \mathrm{~mA}$ tube current and $60 \mathrm{kV}$ excitation. Powder was pressed into 10 tablet with binder $\left(\mathrm{H}_{3} \mathrm{BO}_{3}\right)$ and measured in vacuum. Data was collected for the following major elements: $\mathrm{SiO}_{2}, \mathrm{Al}_{2} \mathrm{O}_{3}, \mathrm{Fe}_{2} \mathrm{O}_{3}, \mathrm{MgO}, \mathrm{K}_{2} \mathrm{O}, \mathrm{TiO}_{2}, \mathrm{CaO}, \mathrm{P}_{2} \mathrm{O}_{5}, \mathrm{Na}_{2} \mathrm{O}, \mathrm{MnO}$ (expressed as wt \%); and minor elements $\mathrm{Ba}, \mathrm{Zn}, \mathrm{Zr}, \mathrm{S}, \mathrm{Cl}, \mathrm{Cr}, \mathrm{Rb}, \mathrm{Ni}, \mathrm{Pb}, \mathrm{Sr}, \mathrm{Nb}, \mathrm{Ce}$, $\mathrm{Y}$ and $\mathrm{Cu}$ (expressed as parts per million - ppm). Statistical procedures and analyses were conducted in a Statistica software package (version 8.0).

\section{Results}

\subsection{The reference diagram Dauwelsmuer}

Mardel Dauwelsmuer (Fig. 3a) is a fen in the debris of a landslide on a sand stone escarpment, developed on the right slope of the river Ernz Noire southwest of Berdorf $\left(49^{\circ} 48^{\prime} 28^{\prime \prime} \mathrm{N} / 6^{\circ} 19^{\prime} 25^{\prime \prime} \mathrm{E}\right.$; altitude $\left.244 \mathrm{~m}\right)$. Such landslides took place in the Late-glacial and Preboreal after the disappearance of the permafrost (Lucius, 1948). During the late summer this fen is dry, the rest of the year it is filled with $10-50 \mathrm{~cm}$ water. The soil is a histic Stagnosol (clayic), overlying a sapric Histosol. Geologically, the profile is a sequence of four formations. The pollen diagram is presented in Fig. 4, the radiocarbon dates are specified in Table 2, the incidental pollen scores in Fig. 5, the macro remains

\section{SOILD}

doi:10.5194/soil-2015-82

\section{Natural versus anthropogenic genesis of mardels \\ on the Gutland \\ plateau}

J. M. van Mourik et al.

\section{Title Page}

Abstract Introduction

Conclusions References

Tables

Figures

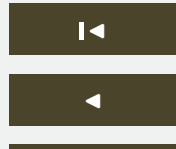

$\Delta$

Back

Close

\section{Full Screen / Esc}

Printer-friendly Version

Interactive Discussion 
The oldest formation (4Ah-4C) consists of gravelly sand, deposited after the landslide on the sand stone debris of the land slide. The $4 \mathrm{C}$ horizon is palynologically sterile. The 4Ah horizon developed in sandy parent material (4C) under deciduous forest. Bioturbation caused pollen infiltration, the pollen densities are low. The infiltrated pollen content 5 of the 4Ah is younger (Atlantic) than the sandy sediment (Late-glacial/Preboreal). The pollen spectra reflect the presence of the Quercetum mixtum, a palynological expression for the sum of the pollen species Quercus, Tilia, Ulmus, Fraxinus and Acer (Faegri and Iversen, 1989). Alnus and Corylus are present as well. Macro remains are very scares in this horizon.

10 The second formation $(3 \mathrm{H})$ consists of sapric peat accumulated from $\approx 6000$ until $\approx 550 \mathrm{BP}$ during the Atlantic, Subboreal and a part of the Subatlantic. The prefix sapric indicates a high degree of decomposition of organic tissues, indicative for a regime of variable water tables during the seasons. The peat accumulation started in the Atlantic around $5400 \mathrm{BC}$ and stopped around AD 1360 in the Subatlantic. During the Atlantic 15 the pollen spectra are dominated by the Quercetum mixtum; the percentages of herbal species are very low. During the Subboreal Alnus expanded. In the beginning of the Subatlantic, Tilia and Ulmus decreased, Fagus and Carpinus appeared. The forest transformed from a Quercetum mixtum into a Fageto-Quercetum. The Fagus curve shows the characteristic regional Subatlantic peaks (Slotboom, 1963), F1 (100 BCAD 200), F2 (AD 700-800), F3 (AD 1200-1300) and F4 (AD 1700-1900). Besides, is the Subatlantic characterized by deforestation (decrease of arboreal pollen, increase of herbal pollen) and extension of agriculture (appearance of culture indicators Cerealia, Secale and Fagopyrum). The macro remains of the $3 \mathrm{H}$ indicate an accumulation of peat in a forested area during this period. Over a distance of about one meter, seeds are regularly present. In the lower $30 \mathrm{~cm}$ of the $3 \mathrm{H}$ horizon we see the combination of wood, bud (-scale) and leaf fragments. The peat above contains wood and bud (scales), the amount declines higher in the $3 \mathrm{H}(50-90 \mathrm{~cm})$. By wood and seeds the presence of some species growing in de tree and shrub layer is demonstrated: Quercus sp., Fraxinus excelsior, Tilia sp., Betula sp., Corylus avellana, Sambucus nigra and Rubus
SOILD

doi:10.5194/soil-2015-82

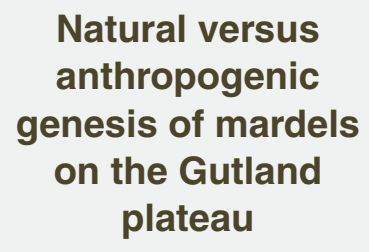

J. M. van Mourik et al.

\section{Title Page}

Abstract

Introduction

Conclusions

References

Tables

Figures

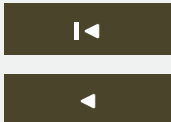

$\rightarrow 1$

Back

D

Back

Close

Full Screen / Esc

Printer-friendly Version

Interactive Discussion 
fruticosus. These species indicate that the peat was formed in a forest. There was no closed canopy since enough light was available for the growth of various swamp plants like Alisma sp. and Carex pseudocyperus. The terrain was wet, but not wet enough for the presence of water plants. Only Callitriche sp. and a Lemna-species 5

could grow in the shallow water puddles, where Cladocera (water flees) and Copepoda (crustaceans) lived as well. All other species found are terrestrial plants which grew in very wet (swamp, shore) to damp habitats. Probably, the groundwater level fluctuated around the ground surface. Such hydrological conditions stimulate the decomposition of folic tissues to sapric peat. The species point to rather nutrient-rich conditions; Urtica 10 dioica is a good example of this.

The third formation $(4 \mathrm{C})$ consists of silty clay and was deposited between $\approx 550$ until $\approx 200$ BP. The increase of herbal pollen (Poacae, Asteraceae, and cultural indicators) points to proceeding deforestation and extension of agriculture. Slotboom and van Mourik (2016) suggested an increase of soil erosion for this period, with maximal 15

values during the Little Ice Age. The Strassen marls on the plateau of Berdorf were the source of the clay, transported by soil erosion to mardel Dauwelsmuer. Fagopyrum is found in the spectra of the clay deposit. The concentration of macro remains in the $2 \mathrm{C}$ horizon is very low.

After the Little Ice Age the accumulation of peat $(\mathrm{H})$ restarted. Picea appeared and 20 Pinus expanded in the pollen records after AD 1800 due to forest plantations, started by the Regional government (Riezebos and Slotboom, 1974, 1978). The macro remains of the upper peat layer $(\mathrm{H})$ contain wood, buds and tree leafs. The tree Fraxinus excelsior is present. Callitriche sp. and water flees (Cladocera) point to a water rich environment. The peat is formed in a swamp forest with shallow puddles and humid land situations.
SOILD

doi:10.5194/soil-2015-82

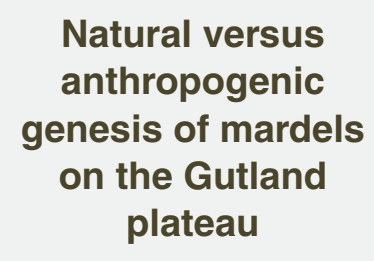

J. M. van Mourik et al.

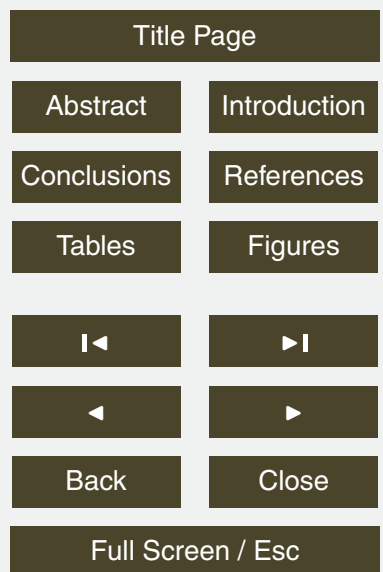

Printer-friendly Version

Interactive Discussion 


\subsection{The pollen diagrams of the mardels on the Steinmergelkeuper}

\subsubsection{Mardel Medernach}

Mardel Medernach (Fig. 3b, pollen diagram Fig. 7) is situated in the Seitert forest, western of Medernach $\left(49^{\circ} 49^{\prime} 06^{\prime \prime} \mathrm{N} / 6^{\circ} 11^{\prime} 75^{\prime \prime} \mathrm{E}\right.$; altitude $\left.324 \mathrm{~m}\right)$. The soil in the mardel

5 filling is a Stagnosol (clayic, colluvic), the soil around the mardel is a stagnic Alisol (clayic), developed in a regolithic cover of $130 \mathrm{~cm}$ weathered Keuper marls. The current dominating soil process is lateral leaching of clay by overland flow and piping, triggered by the dispersion of clayey earth worm droppings (Cammeraat, 2006; Cammeraat and Kooijman, 2009).

10 The oldest zone $(2 \mathrm{C} / 2 \mathrm{Cca})$ is the lower part of the truncated (palaeo)sol, developed in the regolithic cover of the Steinmergelkeuper. The pollen densities in this part the profile are low and show a sharp decrease downwards, characteristic for pollen infiltration (van Mourik, 2001, 2003). The 2C consist of light gray clay with pinkish grey mottles, the 2Cca consist of gritty weathered Steinmergelkeuper. The infiltrated pollen grains are not or slightly corroded, very well preserved under the colluvial layers. The pollen spectra reflect the Fageto-Quercetum. The relatively high percentages of herbal pollen, indicate an open place in the forest. Remarkable is the presence of pollen of the (semi)aquatic species Callitriche and Sagina), These plants do not occur on the drained forest soils in the surroundings and indicate moist to wet conditions at the time of infiltration.

The C2 horizon, light gray clay, is the basic layer of the colluvial filling. A part of the pollen grains is hardly corroded (sin-sedimentary pollen), a part is severely corroded (pollen, originating from the eroded topsoil in the surroundings). Pollen of Callitriche is still present, pointing to wet conditions at the time of deposition. The herbal pollen 25 species decrease, the arboreal species increase, indicating recovering of the forest. Fagus peaks $\mathrm{F} 2$ and $\mathrm{F} 3$ are recognizable, pointing to a palynological age between $\approx 500$ and $\approx A D 1500$.

\section{Natural versus anthropogenic genesis of mardels \\ on the Gutland plateau}

\section{J. M. van Mourik et al.}

\section{Title Page}

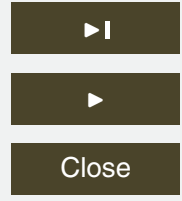


The $\mathrm{C} 1$ horizon, grey clay, is a colluvial layer, deposited since $\approx A D 1500$. The appearance of Fagopyrum and the extension reflect the Little Ice Age. In the AC horizon (dark grey clay) the appearance of Picea reflects the forest plantations after AD 1800.

\subsubsection{Brasert2}

5 The Brasert2 mardel (Fig. 3c, pollen diagram Fig. 8) is situated in the Brasert forest $\left(49^{\circ} 49^{\prime} 42^{\prime \prime} \mathrm{N} / 6^{\circ} 08^{\prime} 48^{\prime \prime} \mathrm{E}\right.$; altitude $\left.356 \mathrm{~m}\right)$ on the Steinmergelkeuper $\left(\mathrm{km}^{3}\right)$ under Fageto-Quercetum. Similar to mardel Medernach, the soil in the mardel filling is a Stagnosol (clayic, colluvic), the soil around the mardel is a stagnic Alisol (clayic), developed in a the regolithic cover of weathered Keuper marls.

10 In previous studies of the mardels in the Brasert forest (Poeteray et al., 1984; Slotboom and van Mourik, 2015) a difference of $150-250 \mathrm{~cm}$ between the level of the weathering front in the calcareous Keuper in the mardels and outside the mardels was established. This difference is explained by subsidence of the surface after de dissolution of gypsum lenses. The thickness of the majority of gypsum lenses and veins, occurring in the Steinmergelkeuper ranges from 0.5 to $3 \mathrm{~m}$ (Lucius, 1948).

The zoning of the pollen diagram (Fig. 8) is similar to diagram Medernach. A truncated palaeosol $(2 \mathrm{C}, 2 \mathrm{Cca})$ had developed in the weathered Keuper marls in which pollen had infiltrated. Relatively high percentages of herbal pollen and aquatics can be observed (in this diagram Myriophyllum and Typha). A colluvial basic layer (C2, gray 20 clay) was deposited between AD 500 and 1000 (before the F2), with pollen spectra reflecting recovering of the forest. A colluvial layer top layer $(\mathrm{C} 1)$ was deposited since AD 1000 with the palynologically reflection of the Little Ice Age and the Picea plantations.

\subsubsection{Michelbouch}

25 Mardel Michelbouch (Fig. 3d, polen diagram Fig. 9) is located in the "Biischtert" forest, east of Michelbouch $\left(49^{\circ} 48^{\prime} 58^{\prime \prime} \mathrm{N} / 6^{\circ} 01^{\prime} 55^{\prime \prime} \mathrm{E}\right.$; altitude $\left.357 \mathrm{~m}\right)$. In the mardel filling a
SOILD

doi:10.5194/soil-2015-82

Natural versus anthropogenic genesis of mardels

on the Gutland

plateau

J. M. van Mourik et al.

\section{Title Page}

Abstract Introduction

Conclusions References

Tables Figures

14 4

\section{Full Screen / Esc}

Printer-friendly Version

Interactive Discussion 
Stagnosol (clayic, colluvic) was discovered and in the forested surroundings a stagnic Alisol (clayic) was present.

The zonation of the diagram (Fig. 9) is rather similar to the diagrams Medernach and Brasert2. Two differences can be noticed: the distinction of three instead of two colluvial 5 layers and the presence of a well-developed $\mathrm{F}$ horizon. The basic layer (2C, light grey silty clay with grey pinkish mottles) is part of the truncated palaeosol, with infiltrated pollen, reflecting a moist to wet open environment. It was not possible to reach the $2 \mathrm{Cca}$ horizon with the auger on this site. The oldest colluvial layer (C3, light grey clay) is deposited after the Roman Time but before the F3. All the spectra show high per10 centages of herbal pollen. The C2 (grey clay) layers was deposited between $\approx A D 100$ and $\approx 1500$. The pollen spectra reflect the forest recovery. The pollen densities in this humic colluvial layer show high values. The colluvial top layer ( $\mathrm{C} 1$, light grey clay) was deposited since AD 1500 and reflects the appearance of Fagopyrum and Picea like in the diagrams of Medernach and Brasert2.

\subsubsection{Archaeometrical results}

Table 2 presents the results of the grain size analyses of samples from mardel colluvium and the surrounding soils. The $\mathrm{pH}$ values ranges from weak acid to neutral, the percentages organic carbon from 1.9 to 10.9. The texture of the mardel samples is clay, of the soils samples clay or clay loam. This reflects the results of soils erosion and clay dispersion of the earth worm droppings (Cammeraat and Kooijman, 2009).

Table 3 presents the chemical results of the WD-XRF analyses of fourteen samples. Soils (S samples) and mardels (M samples) are derived from the sites under study: Beaufort (BEAU), Medernach (MED), Michelbouch (MICH), Brasert (BRAS) and Berdorf (BER).

25 A multivariate statistical analysis was conducted to determine group attribution and variability of the soils, mardels and archaeological ceramic samples. The PCA scores were calculated on $\log _{10}$ transformed concentration values (in ppm). Elements $\mathrm{SiO}_{2}$,
SOILD

doi:10.5194/soil-2015-82

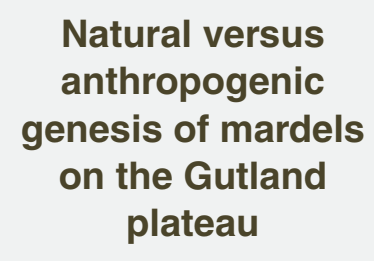

J. M. van Mourik et al.

\section{Title Page}

Abstract

Introduction

Conclusions

References

Tables

Figures

14

4

Back

Close

Full Screen / Esc

Printer-friendly Version

Interactive Discussion 
$\mathrm{CaO}, \mathrm{TiO}_{2}, \mathrm{~K}_{2} \mathrm{O}, \mathrm{Fe}_{2} \mathrm{O}_{3}, \mathrm{MgO}, \mathrm{Na}_{2} \mathrm{O}, \mathrm{Al}_{2} \mathrm{O}_{3}, \mathrm{Zr}, \mathrm{Sr}, \mathrm{Cr}, \mathrm{Rb}$ and $\mathrm{Ba}$ were retained for this analysis.

The abundances of major and trace elements are fairly consistent for most elements in the ceramic materials. All analyses from the same locale, i.e. soil and mardel show 5 similar geochemical values. Nevertheless, significant variation is present between the uniform ceramic materials and some mardel and soil samples. The compositional analyses from the mardels at Michelbouch and Brasert are highly similar and consistent with chemical values the ceramics. Generally $\mathrm{SiO}_{2}$ content is higher in both the mardel and soil samples opposite to the ceramic materials. Total $\mathrm{Fe}_{2} \mathrm{O}_{3}$ content is in general 10 also slightly elevated. The alkalis show uniform concentrations for $\mathrm{Na}_{2} \mathrm{O}(\sim 0.3 \mathrm{wt} \%)$ but are quite variable in $\mathrm{K}_{2} \mathrm{O}$ concentrations (from $~ 2$ to $3.5 \mathrm{wt} \%$ ).

A SiO ${ }_{2} / \mathrm{Al}_{2} \mathrm{O}_{3}$ plot (Fig. 10) is often used as a grain size indicator in geological studies (Dypvik, 1979). A higher proportion of quartz/coarse fractions cause higher $\mathrm{SiO}_{2}$ values. Clay-based material suitable for ceramic production, with good grain size distri15 bution should have a higher content in aluminum. This is clearly the case for all ceramic samples as well as the mardels from Michelbouch and Brasert. All soil samples have generally higher $\mathrm{SiO}_{2}$ values and are therefore richer in a sand fraction.

A bivariate plot of $\mathrm{K}_{2} \mathrm{O}$ versus $\mathrm{MgO}$ (Fig. 11) clearly separate both soil and mardel samples from Beaufort and Berdorf, excluding them as potential sources for the pro20 duction of the local ceramics form the Biischtert near Michelbouch.

A cluster analysis through PCA analysis was carried out incorporating the multivariate aspect of the compositional data. The first two PCs account for nearly $71 \%$ of the variance in the data. Eigenvalues are reported in Table 4.

All samples show low levels of $\mathrm{P}_{2} \mathrm{O}_{5}$ which signifies restricted post depositional al25 terations of the ceramic materials, but was excluded from the statistical analysis.

A graphical output of the principal component analysis defines the presence of at least two distinct groups (Figs. 12 and 13). Group 1 is composed of all ceramic samples, as well as both soils and mardels from Michelbouch and Brasert. A clear separation can be observed with the soil and mardel samples from Berdorf and Beaufort.
SOILD

doi:10.5194/soil-2015-82

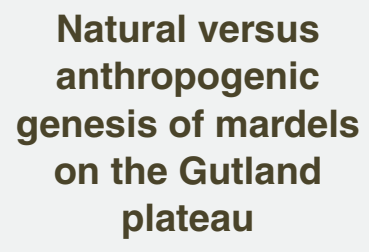

J. M. van Mourik et al.

\section{Title Page}

Abstract

Introduction

Conclusions

References

Tables

Figures

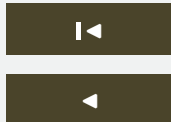

$\rightarrow 1$

Back

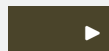

$\triangleright$

Back

Close

Full Screen / Esc

Printer-friendly Version

Interactive Discussion 
While less distinct than the previous two sites, the mardel and soil composition from Medernach differentiates from the ceramics mainly in terms of a lower $\mathrm{Fe}_{2} \mathrm{O}_{3}(\sim 5 \mathrm{wt} \%$ vs. $~ 9 \mathrm{wt} \%$ ) and higher $\mathrm{MgO}$ content ( $7 \mathrm{wt} \%$ vs. $4.5 \mathrm{wt} \%)$.

Based on these observations it can be concluded that the composition of the mardels 5 from Michelbouch and Brasert are consistent with the ceramic compositions. Moreover the mardels of Berdorf and Beaufort are significantly different from the other mardel and soil samples. These mardels are especially depleted in $\mathrm{MgO}$ content and have significantly lower total Fe values.

\section{Discussion}

10 4.1 Palynological dating of the mardel deposits

The first aim of this study was to determine the natural versus anthropogenic genesis of the mardels on the Steimergelkeuper. We acquired relevant paleoecological information by comparing the zoning of three pollen diagrams of mardel fillings with the zoning of a radiocarbon dated reference diagram.

15 The pollen content of peaty deposits as in profile Dauwelsmuer is sin-sedimentary and the palynochronology is sustained by reliable ${ }^{14} \mathrm{C}$ dates. The pollen content of mardel deposits is partly sin-sedimentary, partly post sedimentary, with consequences for the interpretation of the pollen spectra (van Mourik, 2001, 2003). Dating of such diagrams cannot be based on absolute dates but only on palynochronological markers.

- The transfer of the Quercetum mixtum into Fageto Quercetum (reflected by deciduous tree species) and the start of the anthropogenic deforestation and extension of agriculture (reflected by herbal species and cultural indicators) at the end of the Subboreal (Slotboom and van Mourik, 2016).

- The four peaks of Fagus; F1 (100 BC-AD 200), F2 (AD 700-800), F3 (AD 12001300), F4 (AD 1700-1900) (Persch, 1950; Slotboom, 1963; Daniels, 1964). The

\section{SOILD}

doi:10.5194/soil-2015-82

\section{Natural versus anthropogenic genesis of mardels \\ on the Gutland \\ plateau}

J. M. van Mourik et al.

\section{Title Page}

Abstract

Introduction

Conclusions

References

Tables

Figures

14

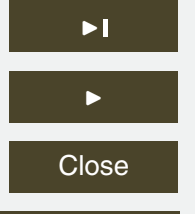

Back

Full Screen / Esc

Printer-friendly Version

Interactive Discussion 
Fagus minima and maxima correlate with the Subatlantic climatic oscillations (Loehle, 2007).

- The appearance of Secale (or the extension of Cerealia) in the Celtic/Roman time (Slotboom and van Mourik, 2016).

- The appearance of Fagopyrum after AD 1450 (Leenders, 1987).

- The expansion of Picea and Pinus after AD 1800 (Slotboom and van Mourik, 2016).

The pollen diagrams of the previous investigated mardel fillings on the Strassen marls (Slotboom and van Mourik, 2015) and the diagrams of the analyzed mardel fillings on 10 the Steinmergelkeuper have some diagnostic palynological characteristics in common.

- The drastic decrease of the pollen densities from the colluvial basic layer into the weathered marls, pointing to truncation of the former soil in the Steinmergelkeuper by excavation of pre Roman colluvium.

- The mardel fillings are Subatlantic (post Roman), deposited after the transition of the Quercetum mixtum into the Fageto Quercetum and the F4.

- The pollen spectra of the basic layers of the colluvial deposits contain species from (semi)aquatic plants.

- Some pollen, including (semi)aquatics, infiltrated into the truncated marl soil (low pollen density).

- Cerealia are present in all the horizons of the deposits.

- (Some) peaks of Fagus are observable in the diagrams.

- The appearance of Fagopyrum is observable.

- The extension of Pinus and Picea is observable.

\section{Natural versus anthropogenic genesis of mardels \\ on the Gutland \\ plateau}

J. M. van Mourik et al.

\section{Title Page}

Abstract

Introduction

Conclusions

References

Tables

Figures

14

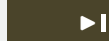

4

Back

Close

Full Screen / Esc

Printer-friendly Version

Interactive Discussion 
The interpretation of the forest dynamics, reflected by the pollen records, e.g. the forest transition and the Subatlantic Fagus peaks, and the impact on soil erosion and colluviation needs some additional remarks.

a. The pollen content of the basic layers of mardel deposits (the truncated soil in weathered Steinmergelkeuper) is post sedimentary; consequently, the age of the parent material is older than the palynological age.

b. The pollen composition of the colluvial layers is a mix of aeolian pollen deposition and pollen present in eroded and redeposited slope material. Consequently, older and corroded pollen grains are mixed with sin-sedimentary fresh pollen. Beside, pollinating species occurring on the eroded slopes can be overrepresented in pollen extractions of colluvium.

c. Wind pollinated species are overrepresented in pollen spectra, insect pollinated species underrepresented. Besides, it is known that the pollen production and dispersion of wind pollinated species can vary significantly. This is an important topic for a correct interpretation of the Fagus peaks.

d. The pollen production of a monoculture of Quercus is around $35 \times 10^{6} \mathrm{ha}^{-1}$, of Fagus around $20 \times 10^{6} \mathrm{ha}^{-1}$ (Andersen, 1970). Consequently, a displacement of Fagus by Quercus inside a forest stand can result in an increase of the total scores of arboreal pollen that is not related to forest extension (Faegry and Iversen, 1989).

e. Optimal environmental conditions for the Fageto-Quercetum are base rich substrates, a mean annual temperature of $7-9^{\circ} \mathrm{C}$, annual precipitation of 600 $800 \mathrm{~mm}$ and a topographical altitude of 200-550 $\mathrm{m}$ (Slotboom and van Mourik, 2015). Fluctuations in temperature and precipitation affected the ratio between Quercus and Fagus trees (Loehle, 2007). The colder and wetter climate during the Dark Ages and the Little Ice Age promoted the extension of Quercus trees at the expense of Fagus, warmer and moister conditions during the Roman Time

\section{SOILD}

doi:10.5194/soil-2015-82

\section{Natural versus anthropogenic genesis of mardels \\ on the Gutland \\ plateau}

J. M. van Mourik et al.

\section{Title Page}

Abstract Introduction

Conclusions References

Tables Figures

14

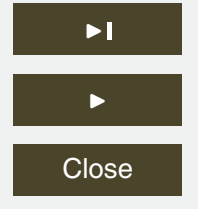

Back

Full Screen / Esc

Printer-friendly Version

Interactive Discussion 
and Middle Ages promoted the extension of the Fagus trees (Slotboom and van Mourik, 2015).

f. There is no consensus in the literature on the question whether the decline of Tilia in the Quercetum mixtum during the Subboreal is the consequence of human activities or of the $2-3^{\circ} \mathrm{C}$ decline in summer temperatures. Firbas (1949) suggested a crucial role of the climate in the decline of Tilia. Fanta (1995) suggested that in the northwestern lowlands Fagus arrives in the Subboreal by natural migration; the decline of Tilia and the extension of Fagus during the Celtic/Roman Time (F1) was promoted by a moister soil regime and an increasing temperature, but also the Neolithic population contributed to the decline of Tilia by tree cutting and using the leafs, bark and wood.

g. Before the arrival of Fagus in the Gutland the deposition rate of alluvium on valley floors was low, indicating a low rate of soil erosion under the Quercetum mixtum (Slotboom and van Mourik, 2014). It is assumed that the Fagus trees in the Fageto-Quercetum promote soil acidification, clay dispersion and soil erosion (Cammeraat, 2006; Cammeraat and Kooijman, 2009).

h. Based on studies of valley floor deposits (Slotboom and van Mourik, 2016) it was suggested that the rate of soil erosion and accumulation of colluvium on valley floors and in mardels accelerated in the Subatlantic due to deforestation. During the Subatlantic climatic oscillations and land use controlled the rate of soil erosion, as demonstrated in the profile studies of the mardels Brasert and Kalefeld (Poeteray et al., 1984; Slotboom and van Mourik, 2015).

i. Palynologically, the extension of arable land at the expense of pasture in a deforested landscape was observed from AD 1500-1800 (the Little Ice Age) (Poeteray et al., 1984). Farmers continued with the development of the cultural landscape, but probably they switched to crops, resistant to colder and wetter climatic circumstances, like Fagopyrum (Slicher van Bath, 1960). The increase of soil erosion

SOILD

doi:10.5194/soil-2015-82

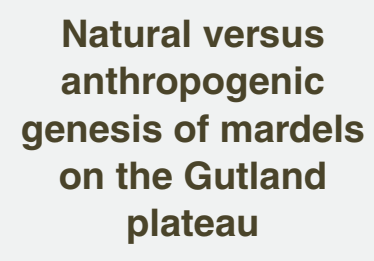

J. M. van Mourik et al.

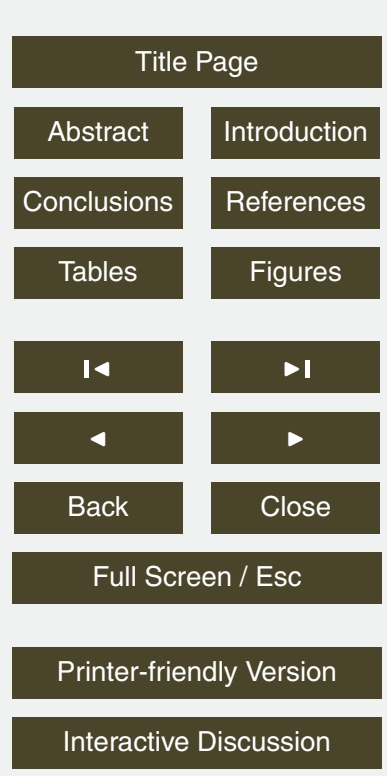


during the Little Ice Age is clearly recorded in the Dauwelsmuer diagram by the deposition of the clay layer (3).

j. The development of subsidence basins on the Steinmergelkeuper proceeded during the entire Holocene. Also soil erosion is a process that proceeded during the entire Holocene. However, soil erosion accelerated in the Subatlantic and during the entire Holocene mardels functioned as sediment trap and were filled with colluvium, before and after Roman Time.

\subsection{Archaeometrical matching of mardel clay and Roman ceramics}

The second aim of this study was to answer the question if Romans extracted clay from mardels for the production of ceramics. This was investigated by archaeometrical comparison of the properties of various potential source materials for the production of ceramics to clay samples from mardel deposits and surrounding soils.

The results show a reliable matching of the properties of the Roman potsherds of the Biischtert excavation site with clay samples from the mardels and surrounding soils on the Steinmergelkeuper (firstly Michelbouch, but also Brasert2 and Medernach).

The properties of the clay samples of the Strassen marls are different. The textural properties of the clay samples from the mardels and surrounding soil indicate suitable material for the production of ceramics. To confirm the match of this source material with ceramics, a comparison with findings from an excavation site on the Strassen marls is required. However, currently no such findings were present at our disposal.

\subsection{Natural and anthropogenic genesis of mardels}

It is assumed that the Romans preferred the mardels as preferred sites for the extraction of clay to produce ceramics. They could excavate clay in mardels on the Gutland plateau, close to the settlements, for the production of ceramics. Other sources, such (Slotboom and van Mourik, 2016).

\section{Natural versus anthropogenic genesis of mardels \\ on the Gutland \\ plateau}

J. M. van Mourik et al.

\section{Title Page}

Abstract Introduction

Conclusions References

Tables Figures

14 4

Back Close

\section{Full Screen / Esc}

Printer-friendly Version

Interactive Discussion 
The mardels in the Gutland, developed on the Strassen marls $\left(\mathrm{Ii}^{3}\right)$ are the result of historical clay excavation (Slotboom and van Mourik, 2015); the published pollen diagrams (Berdorf and Beaufort) demonstrate a post Roman age for the colluvial fillings of these mardels on a truncated soil in weathered marls. Most probably, the excavation 5 started in shallow, moist depressions in the relief, related to the joint patterns in the underlying sandstone $\left(\mathrm{li}^{2}\right)$ formation.

The mardels on the Steinmergelkeuper $\left(\mathrm{km}^{3}\right)$ developed as subsidence basins, caused by the dissolution of subsurface gypsum lenses and veins. Such basins developed since the Early Holocene (Barth, 1996; Thoen and Hérault, 2006). These depressions functioned as sediment traps. The Romans excavated the pre Roman mardel fillings, at first in the bigger mardels, later on also in the smaller ones. Not only the colluvial filling was extracted but also the top of the underlying (soft) soil in the weathered marls. Afterwards, the deposition of clayey colluvium restarted in the abandoned quarries. The development of mardels on the Steinmergelkeuper is summarized in Fig. 14.

\section{Conclusions}

Palynological dating demonstrated a post Roman age of the mardel fillings on the Strassen marls and on the Steinmergelkeuper.

- these fillings were deposited on the floor of an excavation;

- Romans excavated pre Roman colluvium (including the soft topsoil), deposited in initial natural depressions for the production of ceramics;

- archaeometrical tests demonstrate the match between the properties of clay from mardels on the Steinmergelkeuper and fragments of ceramics, found on the Biischtert excavation site;
SOILD

doi:10.5194/soil-2015-82

\section{Natural versus anthropogenic genesis of mardels \\ on the Gutland \\ plateau}

J. M. van Mourik et al.

\section{Title Page}

Abstract

Introduction

Conclusions

References

Tables

Figures

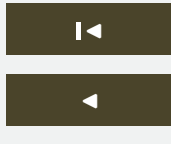

$-1$

Back

Close

\section{Full Screen / Esc}

Printer-friendly Version

Interactive Discussion 
- the combination of palynological and archaeometrical data show that the mardels on the Gutland plateau developed initially as natural depressions, afterwards they were transformed into the present shapes by excavation.

Acknowledgements. We honourable dedicate this article to the late dr. Ruud Slotboom. The 5 first results of the research of the Gutland mardels have been published by him in his PhD thesis (Slotboom, 1963). 50 years later, triggered by the contrasting results of researchers as Etienne et al. (2011), we decided to return to the Gutland to find new data to contribute to the controversial issue natural/anthropogenic mardel genesis. Some preliminary results concerning the mardels on the Strassen marls have been published (Slotboom and van Mourik, 2015)

10 short before Ruud passed away in February 2015. The authors of this paper decided to finish the Gutland mardel study with the diagrams of the mardels on the Keuper marls and the final archaeometrical tests to correlate mardel deposits and Roman pottery.

We are grateful to Roman Jacoby for his scientific advices and for the delivery of the fragments of Roman pottery from the collection of Biischtert for the archaeometrical tests.

We would like to thank Annemarie Philip (IBED, University of Amsterdam) for the preparation of the pollen slides, Leo Hoitinga (IBED, University of Amsterdam) for the grain size analyses of the clay samples, taken from mardel deposits and the surrounding soil and Jan van Arkel (IBED, University of Amsterdam) for the creation of the digital illustrations.

Ruud Hendrikx at the Department of Materials Science and Engineering of the Delft University of Technology is acknowledged for help with the X-ray analysis.

\section{References}

Andersen, S. T.: The relative pollen productivity and pollen representation of North European trees, Denmarks Geol. Unders R2 Nr. 96, 1-99, 1970.

Barth, B.: Mardellen im Lotharingischen Gipskeuper, Delattinia, 22, 7-60, 1996.

25 Braekmans, D., Degryse, P., Poblome, J., Neyt, B., Vyncke, K., and Waelkens, M.: Understanding Ceramic Variability: An archaeometrical interpretation of the Classical and Hellenistic ceramics at Düzen Tepe and Sagalassos (Southwest Turkey), J. Archaeol. Sci., 38, 21012115, 2011.

Braque, R.: Observation sur les mardelles du plateau nivernais, Bulletin de l'Association

\section{SOILD}

doi:10.5194/soil-2015-82

\section{Natural versus anthropogenic genesis of mardels \\ on the Gutland plateau}

J. M. van Mourik et al.

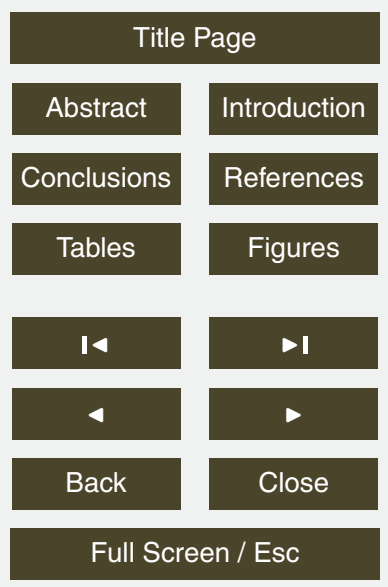

Printer-friendly Version

Interactive Discussion 
Buisman, J. (1995-2006) Duizend jaar weer, wind en water in de lage landen, Vols. 1-5. KNMI, Netherlands.

Cammeraat, L. H.: Luxembourg, in: Soil Erosion in Europe, edited by: Boardman, J. and Poesen, J., John Wiley \& Sons, Chichester, 427-438, 2006.

5 Cammeraat, L. H. and Kooijman, A. M.: Biological control of pedological and hydrogeomorphological processes in a deciduous forest ecosystem, Biologia, 64/3, 428-432, 2009.

Daniels, A. G.: A contribution to the investigation of the Holocene history of the Beech in the Eastern Netherlands, Acta Bot. Neerland. 1, 66-74, 1964.

10 Degryse, P. and Braekmans, D.: Elemental and Isotopic Analysis of Ancient Ceramics and Glass, in: Treatise on Geochemistry, vol. 14, 2nd Edn., edited by: Holland, H. D. and Turekian, K. K., Elsevier, Oxford, 191-207, 2014.

Dypvik, H.: Mineralogy and geochemistry of the Mesozoic sediments of Andya, Northern Norway, Sediment Geol., 24, 45-67, 1979.

Etienne, D., Ruffaldi, P., Goepp, S., Ritz, F., Georges-Leroy, M., Pollier, B., and Dambrine, E.: The origin of closed depressions in Northeastern France: A new assessment, Geomorphology, 126, 121-131, 2011.

Fanta, J.: Beuk (Fagus sylvatica) in het Nederlandse deel van het NW-Europees diluvium, Nederlands Bosbouw Tijdschrift, Apeldoorn, the Netherlands, 225-234, 1995.

20 Faegri, K. and Iversen, J.: Textbook of Pollen Analysis, 4th Edn., John Wiley \& Sons, Chichester, 1989.

Hein, A., Day, P. M., Cau Ontiveros, M. A., and Kilikoglou, V,: Red clays from Central and Eastern Crete: geochemical and mineralogical properties in view of provenance studies on ancient ceramics, Appl. Clay Sci., 24, 245-255, doi:10.1016/j.clay.2003.07.009, 2004.

Heuertz, A. J. and Heyart, H.: Le alluvions de l'Alsette entre Pettange et Moesdorf et leur contenue préhistorique, Institut Grand-Ducal de Luxembourg, section des Sciences, Archive Nouvelle Série, Tome, XXX, 271-296, 1964.

ISRIC-FAO: World Reference Base for Soil Recourses 2006, World soil resources reports 103, Rome, Italy, 2006.

30 Jacoby, R.: Chronologie der Aktivitäten in der Biischtert, De Viichter Geschitsfrënd, 10, 7-10, 2011.

Leenders, K. A. H. W.: De boekweitcultuur in historisch perspectief, Geografisch Tijdschrift, 21, 213-222, 1987.

SOILD

doi:10.5194/soil-2015-82

Natural versus

anthropogenic

genesis of mardels

on the Gutland

plateau

J. M. van Mourik et al.

\section{Title Page}

Abstract

Introduction

Conclusions

References

Tables

Figures

14

4

Back

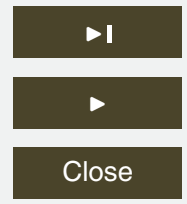

Full Screen / Esc

Printer-friendly Version

Interactive Discussion 
Loehle, C.: A 2000-year global temperature reconstruction based on non-treeing proxies, Energy Environ., 18, 1049-1058, 2007.

Lucius, M.: Beiträge zur Geologie von Luxemburg: Die Ausbildung der Trias am Südrande des Oeslings, Veröffentl. Lux. Geol. Landesaufnahmed, B III, Luxemburg, 1941.

5 Lucius, M.: Geologie Luxemburgs; Erläuterungen zu der Geologischen Spezialkarte Luxemburgs, band V, Service Géologique de Luxembourg, Luxembourg, 1948.

Mook, W. G. and Streurman, H. J.: Physical and chemical aspects of radiocarbon dating, Proceedings of the First International Symposium: 14C and Archaeology, PACT 8, Groningen, 31-55, 1983.

10 Moore, P. D., Webb, J. A., and Collinson, M. E.: Pollen Analyses, Blackwell Scientific Publications, Oxford, 1991.

Osmond, C. B., Valaane, N., Haslam, S. N., Uotila, P., and Roksandic, Z.: Comparisons of $\delta^{13} \mathrm{C}$ values in leaves of aquatic macrophytes from different habitats in Britain and Finland, Oecologia, 50, 117-124, 1981.

15 Persch, F.: Zur postglazialen Wald- und Morentwicklung im Hohen Venn, Decheniana, Bonn, Germany, 81-93, 1950.

Poeteray, F. A., Riezebos, P. A., and Slotboom, R. T.: Rates of Subatlantic lowering calculated from mardel-trapped material (Gutland, Luxembourg), Z. Geomorphol., 1984, 467-482, 1984.

20 Riezebos, P. A. and Slotboom, R. T.: Palynology in the study of present day hill slope development, Geologie en Mijnbouw, 5, 436-448, 1974.

Riezebos, P. A. and Slotboom, R. T.: Pollen analysis of the Husterbaach peat (Luxembourg): its significance for the study of sub recent geomorphological events, Boreas, 7, 75-82, 1978.

Schmalen, C.: Einige Mardellen Luxemburgs auf den Keuper-und Liasschichten des Forstamtbezirks Zentrum, Diplomarbeit in Studiengang Umweltplannung an der Fachhochschule Trier, Standort Birkenfeld, 2002.

Schmidt, G.: Cartographie de biototpes de Medernach; le plateau des fermes de Savelborn, Oeko Fonds, Medernach, Luxembourg, 1995.

Schwenninger, J. L.: Pollen analysis and community structureof Holocene forests: A regional 30 palynological study of the Middle and Upper Postglacial from semi-subhydric alder carr sediments at Berdorf (Luxembourg), Bulletin Société des naturalistes luxembourgeois, 89, 157196, 1989.

SOILD

doi:10.5194/soil-2015-82

\section{Natural versus \\ anthropogenic \\ genesis of mardels \\ on the Gutland \\ plateau}

J. M. van Mourik et al.

\section{Title Page}

Abstract

Introduction

Conclusions

References

Tables

Figures

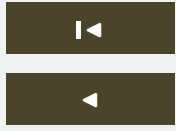

$\Delta$

Back

Close

\section{Full Screen / Esc}

Printer-friendly Version

Interactive Discussion 
Slicher van Bath, B. H.: De agrarische geschiedenis van West Europa, Uitgave Spectrum, Aula 32, Utrecht, the Netherlands, 1960.

Slotboom, R. T.: Comparative geomorphological and palynological investigation of the pingos (Viviers) in the Haute Fagnes (Belgium) and the Mardellen in the Gutland (Luxembourg), Z. Geomorphol., 7, 193-231, 1963.

Slotboom, R. T. and van Mourik, J. M.: Pollen records of mardel deposits; the effects of climatic oscillations and land management on soil erosion in Gutland, Luxembourg, Catena, 132, 72-88, 2015.

Slotboom, R. T. and van Mourik, J. M.: Palynological reconstruction of the effects of Holocene climatic oscillations and agricultural history on soils and landforms in Luxembourg, Springer, Berlin, Germany, 2016.

Thill, G.: Vor- und Frühgeschichte Luxemburgs, Editions Bourg-Bourger, Luxembourg, 1977.

Thoen, D. and Hérault, B.: Flore, groups socio-écologique et typologie de mardelles forestières de Lorrainne belge et luxembourgeoise, Bull. Soc. Luxemb., 107, 3-25, 2006.

van Mourik, J. M.: Pollen and spores, preservation in ecological settings, in: Palaeobiology II, edited by: Briggs, E. G. and Crowther, P. R., Blackwell, Oxford, 315-318, 2001.

van Mourik, J. M.: Life cycle of pollen grains in mormoder humus forms of youngacid forest soils: a micromorphological approach, Catena, 54, 651-663, 2003.

van Mourik, J. M., Wartenbergh, P. E., Mook, W. J., and Streurman, H. J.: Radiocarbon dating of palaeosols in eolian sands, Mededelingen Rijks Geologische Dienst, 52, 425-439, 1995.

Verhoef, P.: Geomorphological and pedological investigations in the Redange-sur-Attert Area (Luxembourg), nr. 8, Publicaties van het Fysisch Geografisch en Bodemkundig Laboratorium van de Universiteit van Amsterdam, Amsterdam, 1966.

\section{Natural versus anthropogenic genesis of mardels \\ on the Gutland plateau}

J. M. van Mourik et al.

\section{Title Page}

Abstract 


\section{SOILD}

doi:10.5194/soil-2015-82

\section{Natural versus anthropogenic genesis of mardels on the Gutland plateau}

Table 1. Radiocarbon dates of the peat deposits of the profile Dauwelsmuer.

\begin{tabular}{lllrl}
\hline GrA code & Sample depth $(\mathrm{cm})$ & Material & ${ }^{14} \mathrm{C}$ age $(\mathrm{BP})$ & Calibrated age $\left(1-\sigma,{ }^{*}\right)$ \\
\hline 63108 & Dauwelsmuer 57.5 & leaf particles & $555 \pm 30$ & AD 1325-1345, 1395-1420 \\
33111 & Dauwelsmuer 102.5 & leaf particles & $4265 \pm 35$ & $2910-2880 \mathrm{BC}$ \\
63110 & Dauwelsmuer 140 & leaf particles & $5035 \pm 35$ & $3940-3860,3815-3775 \mathrm{BC}$ \\
63109 & Dauwelsmuer 195 & leaf particles & $6505 \pm 40$ & $5520-5385 \mathrm{BC}$ \\
\hline
\end{tabular}

${ }^{*}$ Calibrated with OxCal version 4.2.4.

J. M. van Mourik et al.

\section{Title Page}

Abstract

Introduction

Conclusions

References

Tables

Figures

14

4

Back

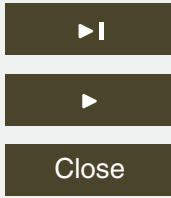

Full Screen / Esc

Printer-friendly Version

Interactive Discussion 


\section{SOILD}

doi:10.5194/soil-2015-82

\section{Natural versus anthropogenic genesis of mardels on the Gutland plateau}

Table 2. pH, LOI and texture of soil and mardel samples.

\begin{tabular}{|c|c|c|c|c|c|c|c|c|c|c|}
\hline \multirow[t]{2}{*}{$\mathrm{pH}$, LOI, texture } & \multicolumn{2}{|c|}{ Beaufort } & \multicolumn{2}{|c|}{ Berdorf } & \multicolumn{2}{|c|}{ Medernach } & \multicolumn{2}{|c|}{ Brasert } & \multicolumn{2}{|c|}{ Michelbouch } \\
\hline & Soil & Mardel & Soil & Mardel & Soil & Mardel & Soil & Mardel & Soil & Mardel \\
\hline $\mathrm{pH}-\mathrm{H}_{2} \mathrm{O}$ & 5.2 & 5.6 & 7.1 & 4.7 & 5.6 & 4.9 & 6.5 & 4.4 & 6.7 & 7.5 \\
\hline $\mathrm{LOI} 375^{\circ} \mathrm{C}$ & 2.1 & 4.9 & 2.4 & 4.6 & 1.9 & 9.6 & 2.0 & 10.9 & 1.9 & 3.8 \\
\hline Texture fraction & [\%] & {$[\%]$} & {$[\%]$} & {$[\%]$} & {$[\%]$} & {$[\%]$} & {$[\%]$} & [\%] & {$[\%]$} & [\%] \\
\hline $2000-63 \mu \mathrm{m}$ & 16.0 & 7.0 & 4.0 & 5.5 & 4.5 & 2.5 & 8.0 & 2.0 & 13.0 & 3.0 \\
\hline $63-32 \mu \mathrm{m}$ & 8.5 & 10.0 & 5.5 & 4.5 & 6.5 & 1.5 & 3.5 & 1.5 & 4.5 & 3.0 \\
\hline $32-16 \mu \mathrm{m}$ & 10.0 & 8.0 & 8.0 & 5.5 & 15.0 & 3.5 & 7.0 & 4.0 & 6.5 & 2.0 \\
\hline $16-8 \mu \mathrm{m}$ & 9.5 & 8.5 & 8.0 & 6.0 & 11.5 & 3.0 & 9.0 & 4.5 & 7.0 & 6.5 \\
\hline $8-4 \mu \mathrm{m}$ & 6.5 & 7.5 & 8.0 & 6.0 & 7.5 & 6.0 & 11.0 & 6.0 & 8.0 & 8.5 \\
\hline
\end{tabular}

J. M. van Mourik et al.

\section{Title Page}

Abstract

Introduction

Conclusions

References

Tables

Figures

14

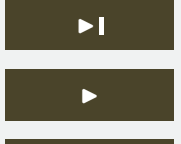

Back

Close

Full Screen / Esc

Printer-friendly Version

Interactive Discussion 


\section{SOILD}

doi:10.5194/soil-2015-82

Table 3. Geochemical composition of all samples (ceramics, mardels and soils) by WD-XRF. Major and minor elements are expressed as wt \% of oxides, trace elements as ppm.

\begin{tabular}{|c|c|c|c|c|c|c|c|c|c|c|c|c|c|c|c|}
\hline \multirow[b]{2}{*}{ Sample } & & \multicolumn{4}{|c|}{ Ceramics } & \multicolumn{5}{|c|}{ Mardels } & \multicolumn{5}{|c|}{ Soils } \\
\hline & & CER-1 & CER-2 & CER-3 & CER-4 & BER-M & BRAS-M & BEAU-M & MED-M & MICH-M & BER-S & BRAS-S & BEAU-S & MED-S & MICH-S \\
\hline $\mathrm{SiO}_{2}$ & wt \% & 57.29 & 58.92 & 60.18 & 58.72 & 68.59 & 60.39 & 71.15 & 63.11 & 61.34 & 71.74 & 62.49 & 71.52 & 64.81 & 65.39 \\
\hline $\mathrm{Al}_{2} \mathrm{O}_{3}$ & wt \% & 22.05 & 21.98 & 20.16 & 21.12 & 20.70 & 19.81 & 19.65 & 19.82 & 21.43 & 17.01 & 21.16 & 19.22 & 18.09 & 19.85 \\
\hline $\mathrm{Fe}_{2} \mathrm{O}_{3}$ & wt \% & 8.53 & 9.25 & 9.59 & 9.62 & 3.98 & 7.95 & 2.24 & 5.35 & 6.49 & 5.54 & 5.86 & 2.98 & 6.21 & 4.81 \\
\hline $\mathrm{MgO}$ & wt \% & 5.55 & 4.41 & 4.23 & 4.40 & 2.02 & 6.33 & 1.88 & 7.02 & 4.96 & 1.53 & 5.32 & 1.92 & 6.80 & 4.37 \\
\hline $\mathrm{K}_{2} \mathrm{O}$ & wt \% & 3.64 & 3.25 & 3.51 & 3.50 & 2.30 & 3.12 & 2.14 & 2.86 & 3.58 & 2.05 & 3.06 & 2.48 & 2.53 & 3.44 \\
\hline $\mathrm{TiO}_{2}$ & wt \% & 1.16 & 1.10 & 1.02 & 1.05 & 1.01 & 1.04 & 0.91 & 0.89 & 1.02 & 1.05 & 0.99 & 0.88 & 0.78 & 1.02 \\
\hline $\mathrm{CaO}$ & wt \% & 0.33 & 0.30 & 0.34 & 0.25 & 0.79 & 0.49 & 1.31 & 0.24 & 0.45 & 0.56 & 0.44 & 0.42 & 0.14 & 0.39 \\
\hline $\mathrm{P}_{2} \mathrm{O}_{5}$ & wt \% & 0.22 & 0.14 & 0.12 & 0.17 & 0.06 & 0.07 & 0.19 & 0.11 & 0.08 & 0.07 & 0.08 & 0.07 & 0.05 & 0.08 \\
\hline $\mathrm{Na}_{2} \mathrm{O}$ & wt \% & 0.22 & 0.20 & 0.30 & 0.29 & 0.23 & 0.28 & 0.20 & 0.31 & 0.26 & 0.21 & 0.27 & 0.21 & 0.32 & 0.29 \\
\hline $\mathrm{MnO}$ & wt \% & 0.09 & 0.07 & 0.09 & 0.06 & 0.01 & 0.19 & 0.01 & 0.03 & 0.07 & 0.03 & 0.03 & 0.03 & 0.06 & 0.03 \\
\hline $\mathrm{Ba}$ & $\mathrm{ppm}$ & 788 & 1065 & 985 & 1191 & 555 & 877 & 519 & 654 & 904 & 448 & 672 & 475 & 600 & 761 \\
\hline $\mathrm{Zn}$ & $\mathrm{ppm}$ & 448 & 376 & 349 & 412 & 54 & 134 & 81 & 90 & 412 & 54 & 81 & 63 & 107 & 313 \\
\hline $\mathrm{Zr}$ & $\mathrm{ppm}$ & 385 & 313 & 331 & 322 & 412 & 322 & 367 & 358 & 295 & 421 & 412 & 394 & 313 & 304 \\
\hline $\mathrm{S}$ & $\mathrm{ppm}$ & 224 & 233 & 412 & 573 & 269 & 295 & 1083 & 403 & 295 & 233 & 466 & 251 & 206 & 304 \\
\hline $\mathrm{Cl}$ & $\mathrm{ppm}$ & 206 & 412 & 1039 & 1665 & 161 & 161 & 242 & 179 & 197 & 143 & 233 & 161 & 188 & 161 \\
\hline $\mathrm{Cr}$ & $\mathrm{ppm}$ & 197 & 197 & 179 & 215 & 152 & 134 & 179 & 179 & 170 & 170 & 161 & 125 & 170 & 215 \\
\hline $\mathrm{Rb}$ & $\mathrm{ppm}$ & 197 & 152 & 179 & 179 & 125 & 197 & 98 & 125 & 161 & 107 & 161 & 107 & 116 & 143 \\
\hline $\mathrm{Ni}$ & $\mathrm{ppm}$ & 152 & 107 & 98 & 81 & 63 & 170 & 63 & 63 & 107 & n.d. & 72 & 81 & 54 & 63 \\
\hline $\mathrm{Pb}$ & $\mathrm{ppm}$ & 63 & 45 & 63 & 54 & 45 & 90 & 45 & 27 & 54 & 45 & n.d. & 63 & 54 & 54 \\
\hline $\mathrm{Sr}$ & $\mathrm{ppm}$ & 63 & 63 & 81 & 81 & 90 & 116 & 81 & 72 & 81 & 98 & 90 & 81 & 63 & 63 \\
\hline $\mathrm{Nb}$ & $\mathrm{ppm}$ & 36 & 27 & 27 & 36 & 27 & 18 & 18 & 18 & 36 & 90 & 18 & 18 & 18 & 27 \\
\hline $\mathrm{Ce}$ & $\mathrm{ppm}$ & n.d. & 385 & 278 & n.d. & 287 & 340 & n.d. & 331 & n.d. & n.d. & 251 & 313 & n.d. & 439 \\
\hline Y & $\mathrm{ppm}$ & n.d. & 45 & 45 & 45 & 45 & 45 & 36 & 27 & 36 & 45 & 36 & 36 & 27 & 36 \\
\hline $\mathrm{Cu}$ & $\mathrm{ppm}$ & n.d. & n.d. & n.d. & n.d. & 501 & 72 & n.d. & 36 & 81 & 63 & n.d. & 439 & n.d. & 81 \\
\hline
\end{tabular}

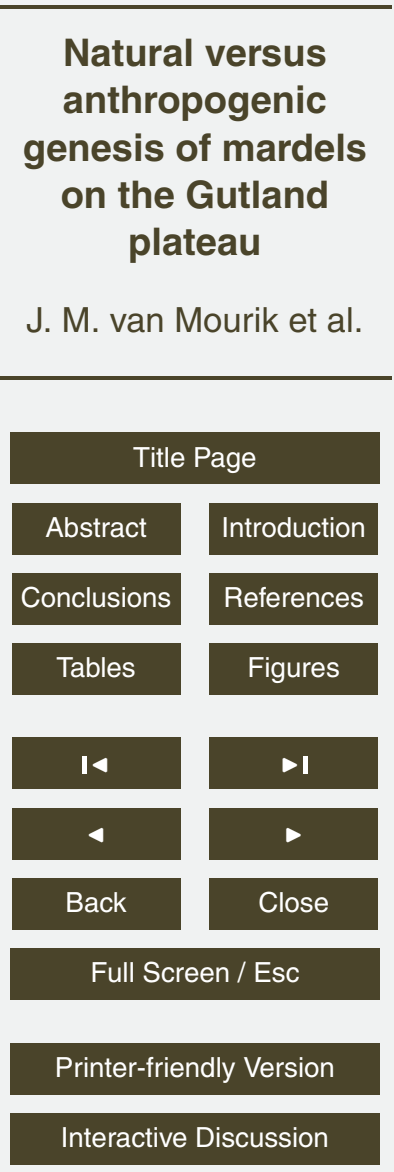




\section{SOILD}

doi:10.5194/soil-2015-82

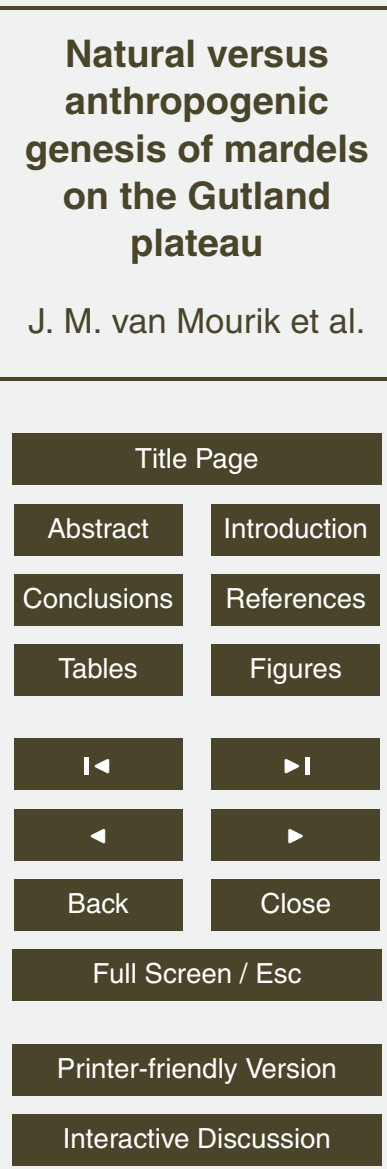




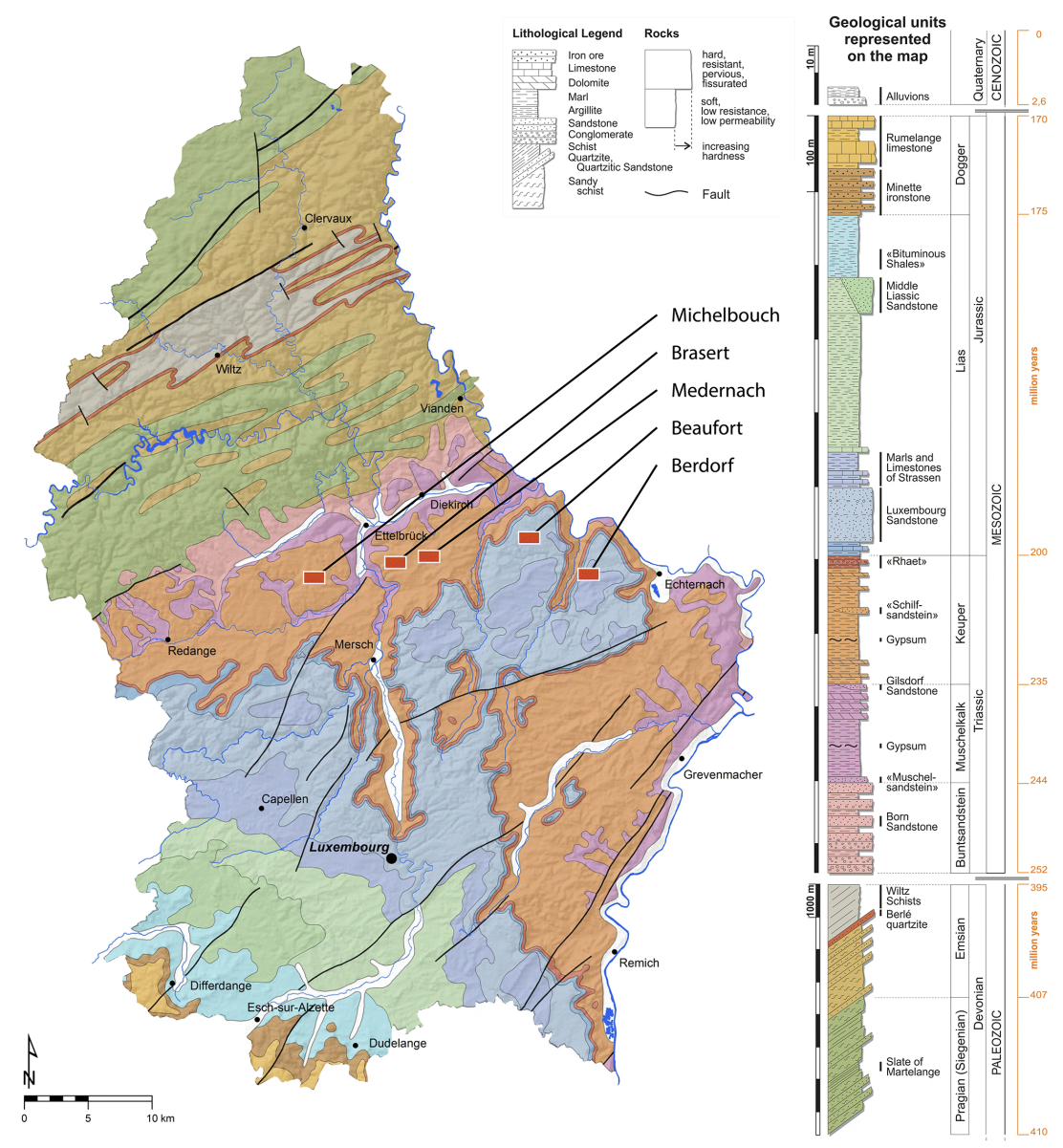

\section{SOILD}

doi:10.5194/soil-2015-82

\section{Natural versus anthropogenic genesis of mardels on the Gutland plateau}

J. M. van Mourik et al.

\section{Title Page}

Abstract

Introduction

Conclusions

References

Tables

Figures

14

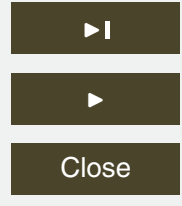

Back

Full Screen / Esc

Printer-friendly Version

Interactive Discussion 

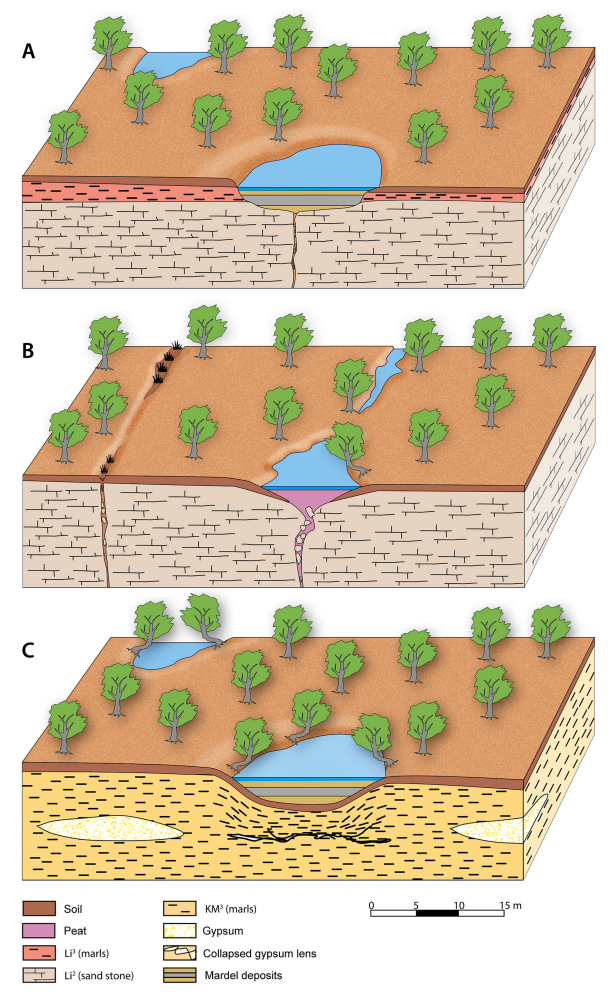

Figure 2. Typology of mardels on various substrates according to Slotboom and van Mourik (2015). (a) Mardels on the Strassen marls $\left(\mathrm{Ii}^{3}\right)$, historical quarries (clay excavations), filled with clayey colluvium. (b) Mardels on the Luxembourger sandstone $\left(\mathrm{li}^{2}\right)$, sink holes determined by faults or joints, filled with sandy colluvium and peat. (c) Mardels on the Steinmergelkeuper $\left(\mathrm{km}^{3}\right)$, subsidence basins caused by subsurface solution of gypsum lenses, filled with clayey colluvium.

\section{SOILD}

doi:10.5194/soil-2015-82

\section{Natural versus anthropogenic genesis of mardels on the Gutland plateau}

J. M. van Mourik et al.

\section{Title Page}

14 4

\section{Full Screen / Esc}

Printer-friendly Version

Interactive Discussion 

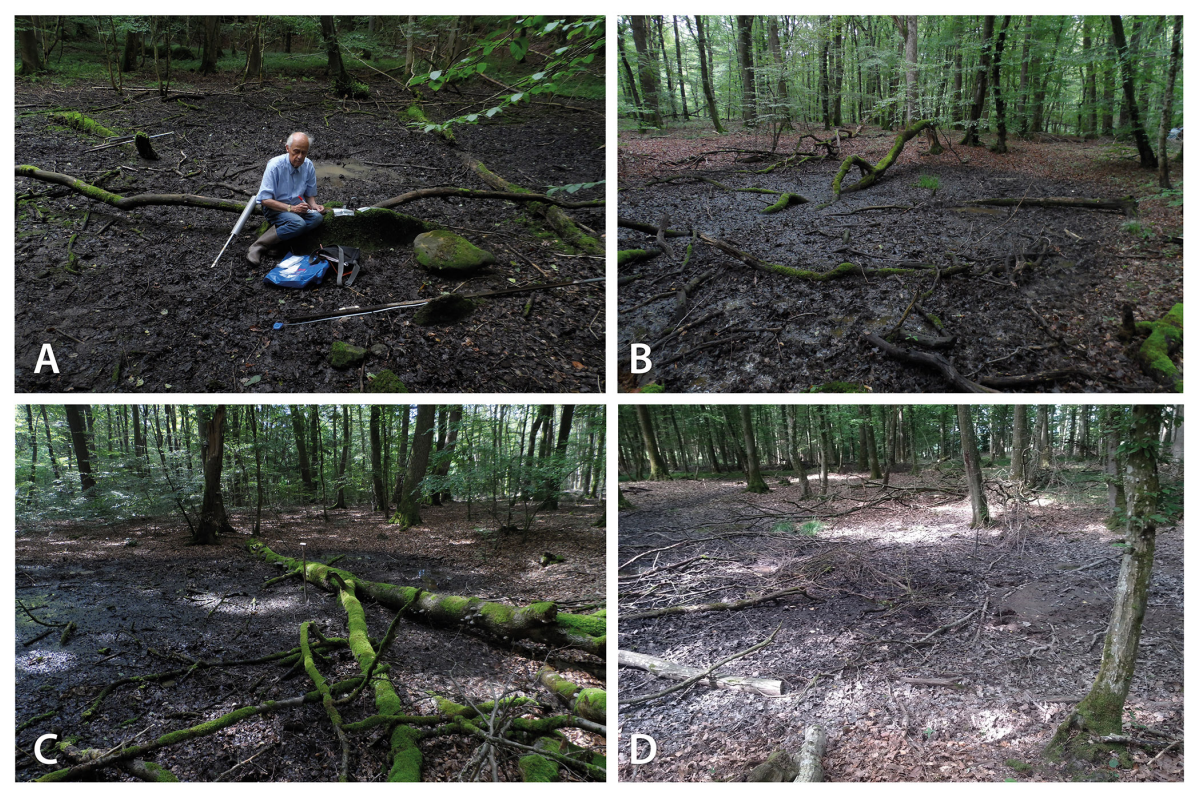

\section{SOILD}

doi:10.5194/soil-2015-82

\section{Natural versus anthropogenic genesis of mardels on the Gutland plateau}

J. M. van Mourik et al.

Figure 3. Pictures of the sampled mardels. (a) Dauwelsmuer July 2014 (with Ruud Slotboom), (b) Medernach July 2014, (c) Brasert2 July 20143, (d) Michelbouch May 2015. Locations of the sample sites indicated in Fig. 1.

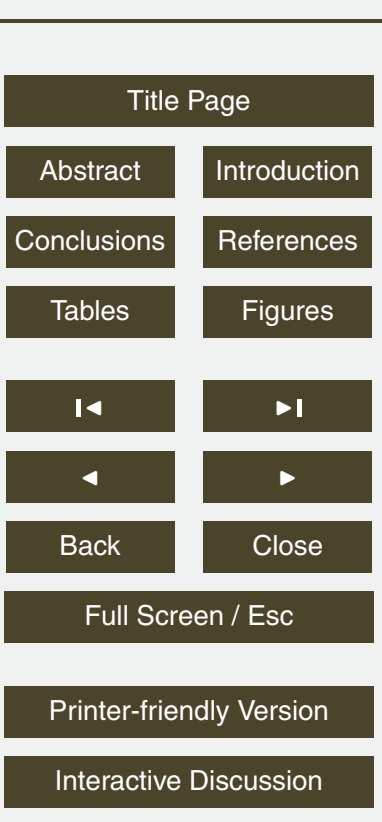




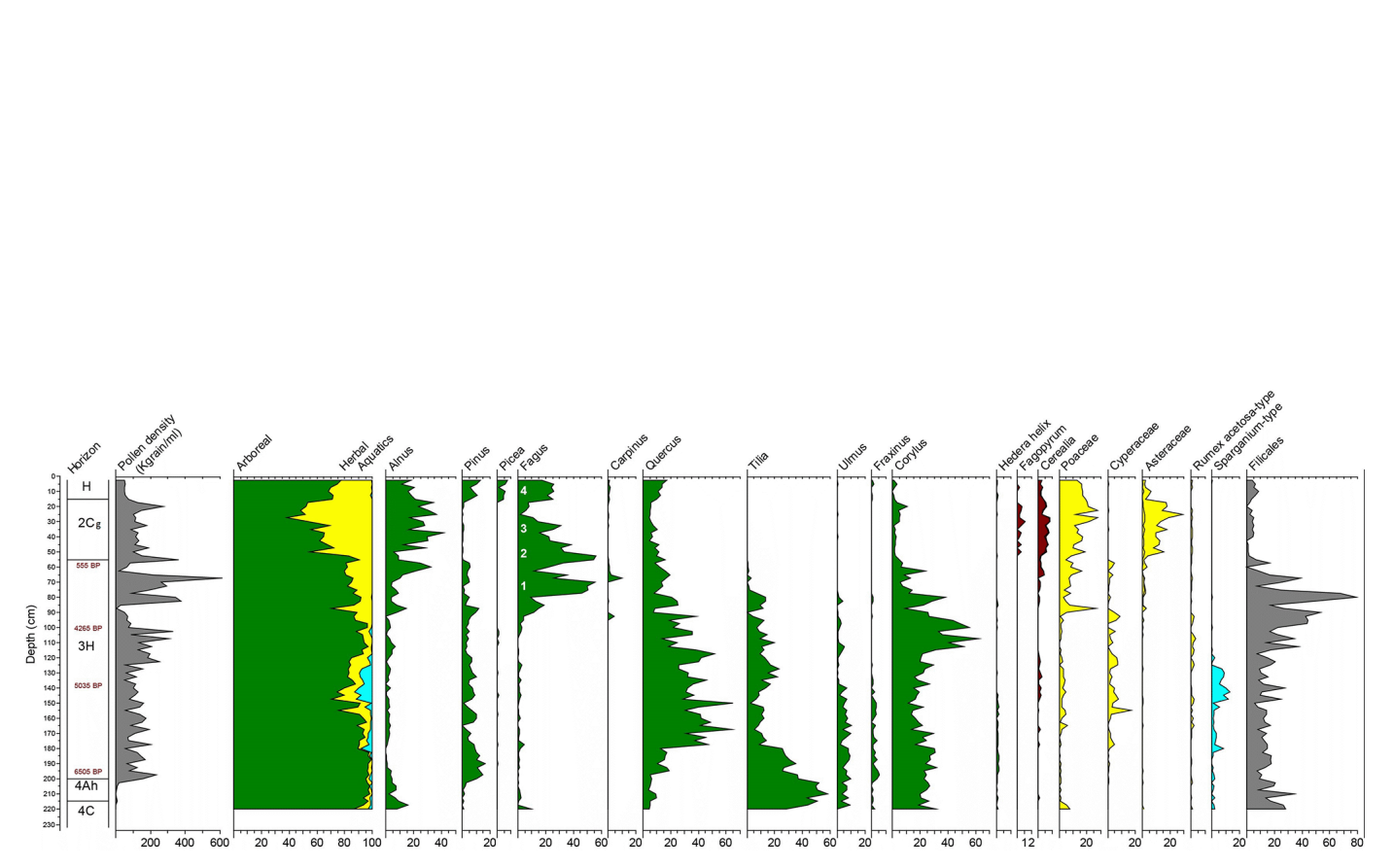

\section{SOILD}

doi:10.5194/soil-2015-82

\section{Natural versus anthropogenic genesis of mardels on the Gutland plateau}

J. M. van Mourik et al.

\section{Title Page}

Figure 4. Pollen diagram Dauwelsmuer. Incidental pollen scores are presented in Fig. 5, macro remains in Fig. 6. Radiocarbon dates (BP) are indicated in the column "Horizon" and specified in Table 1.

\section{4}

4

Back

\section{Full Screen / Esc}

Printer-friendly Version

Interactive Discussion 


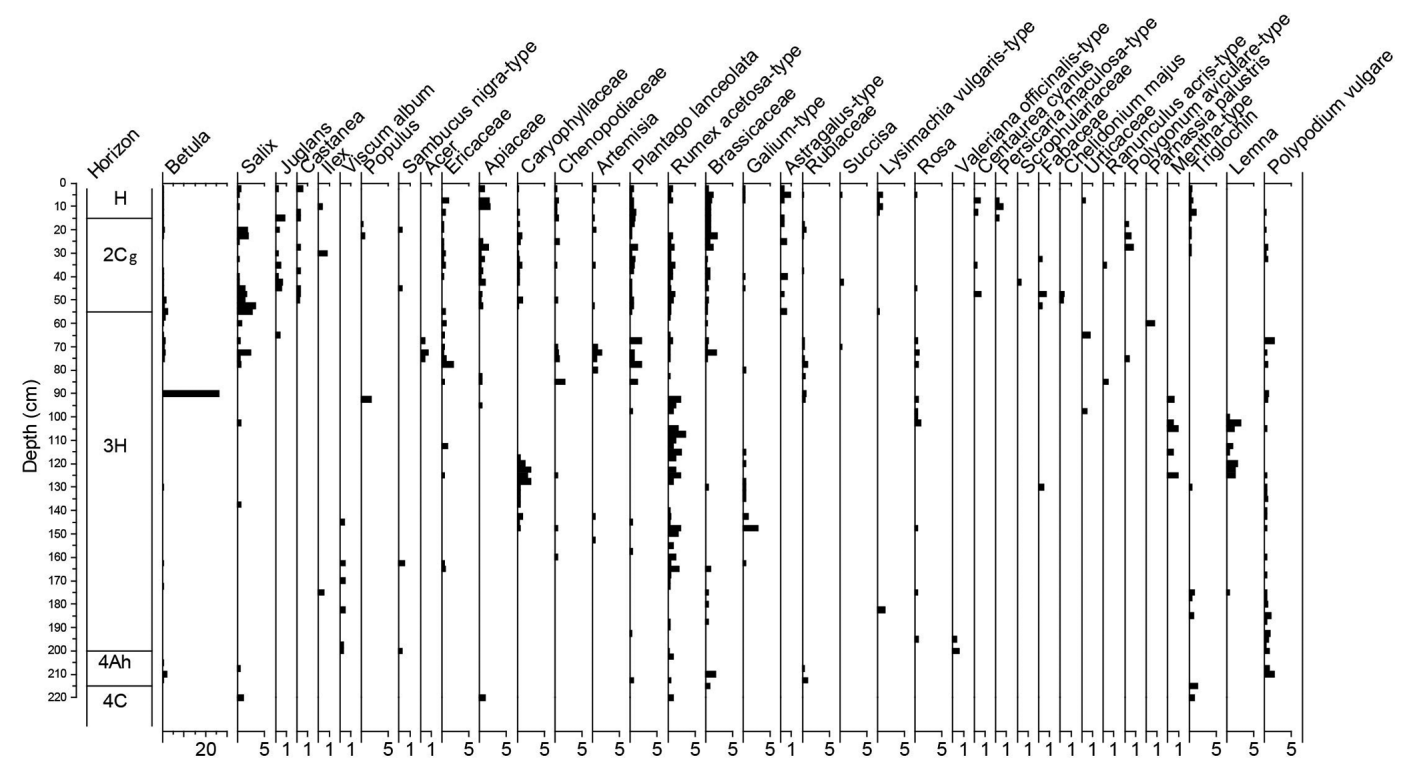

\section{SOILD}

doi:10.5194/soil-2015-82

\section{Natural versus anthropogenic genesis of mardels on the Gutland plateau}

J. M. van Mourik et al.

\section{Title Page}

14

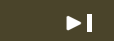

4

\section{Full Screen / Esc}

Printer-friendly Version

Interactive Discussion 


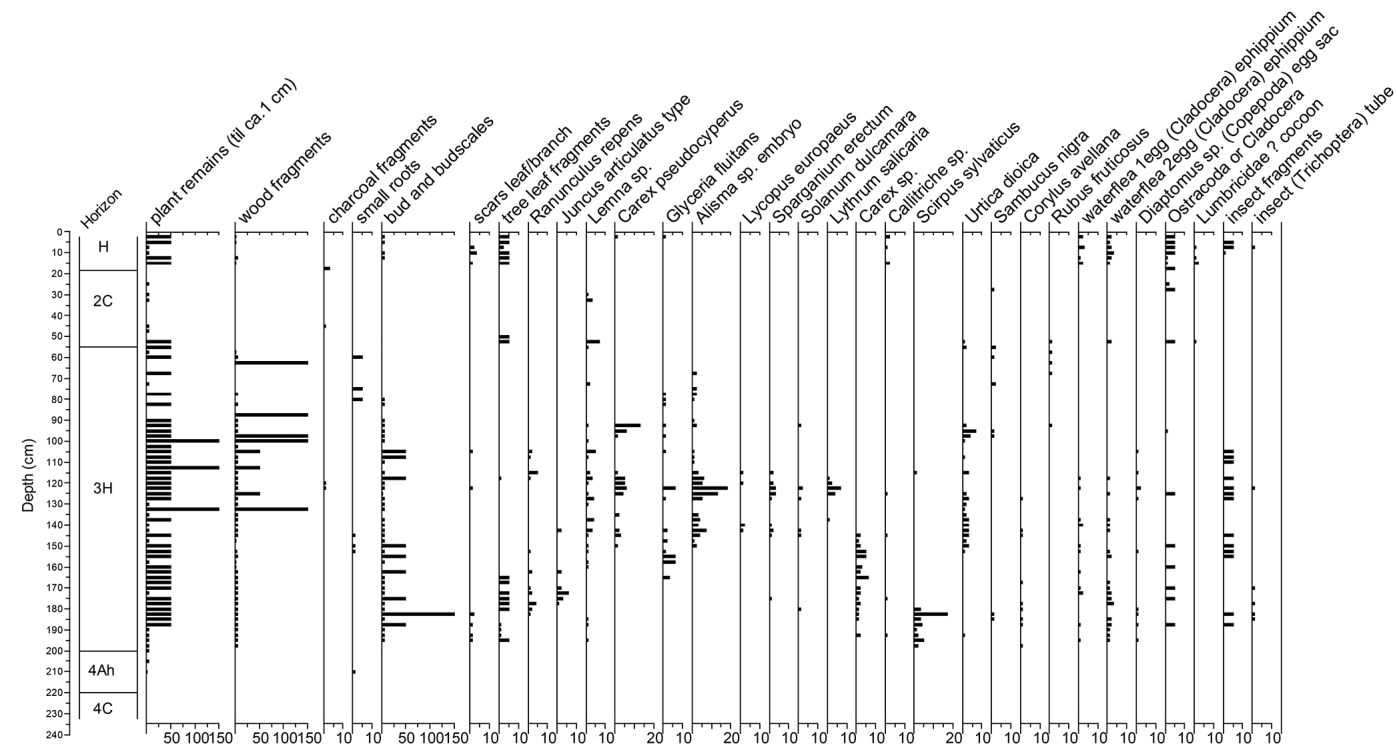

SOILD

doi:10.5194/soil-2015-82

\section{Natural versus anthropogenic genesis of mardels on the Gutland plateau}

J. M. van Mourik et al.

\section{Title Page}

Abstract

Introduction

Conclusions

References

Tables

Figures

14

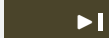

Full Screen / Esc

Printer-friendly Version

Interactive Discussion 


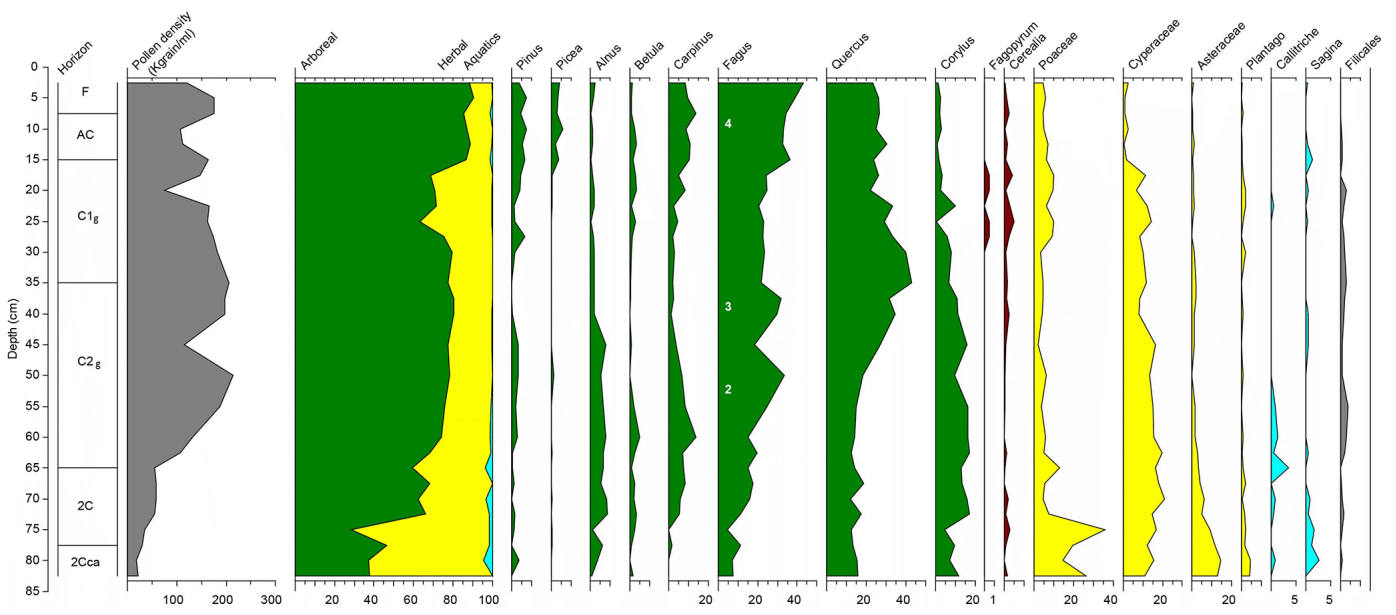

\section{SOILD}

doi:10.5194/soil-2015-82

\section{Natural versus anthropogenic genesis of mardels on the Gutland plateau}

J. M. van Mourik et al.

\section{Title Page}

14

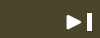

Figure 7. Pollen diagram Medernach.

Back

\section{Full Screen / Esc}

Printer-friendly Version

Interactive Discussion 


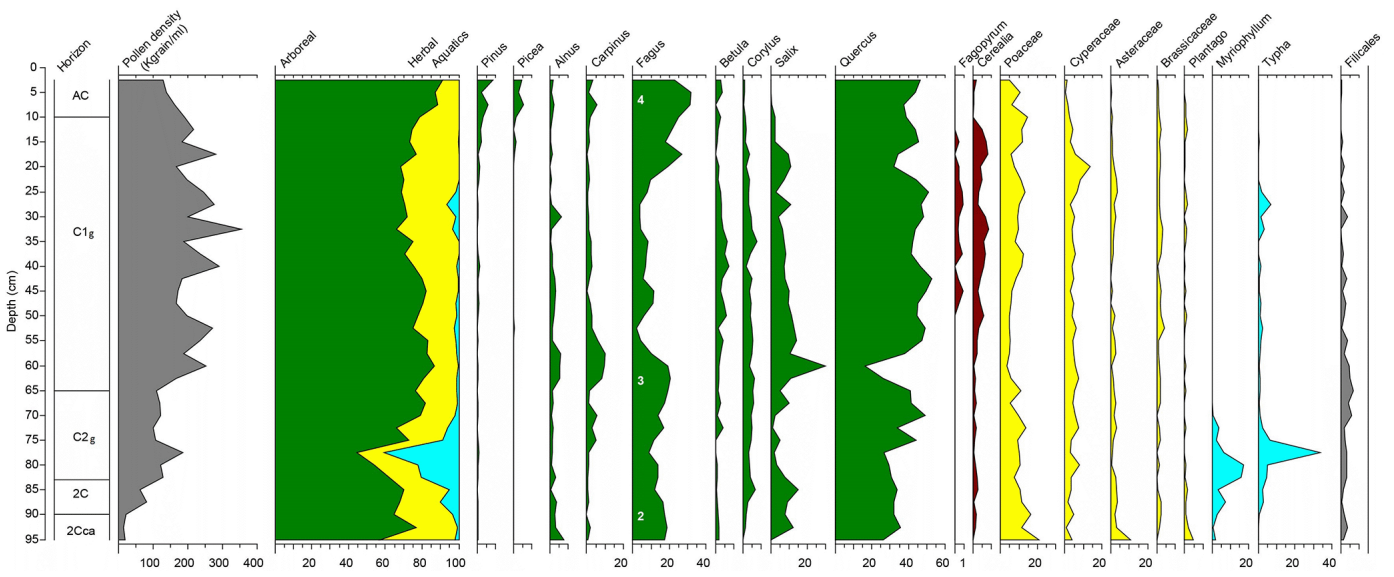

\section{SOILD}

doi:10.5194/soil-2015-82

\section{Natural versus anthropogenic genesis of mardels on the Gutland plateau}

J. M. van Mourik et al.

\section{Title Page}

Abstract

Introduction

Conclusions

References

Tables

Figures

14

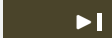

Figure 8. Pollen diagram Brasert2.

$>$

Full Screen / Esc

Printer-friendly Version

Interactive Discussion 


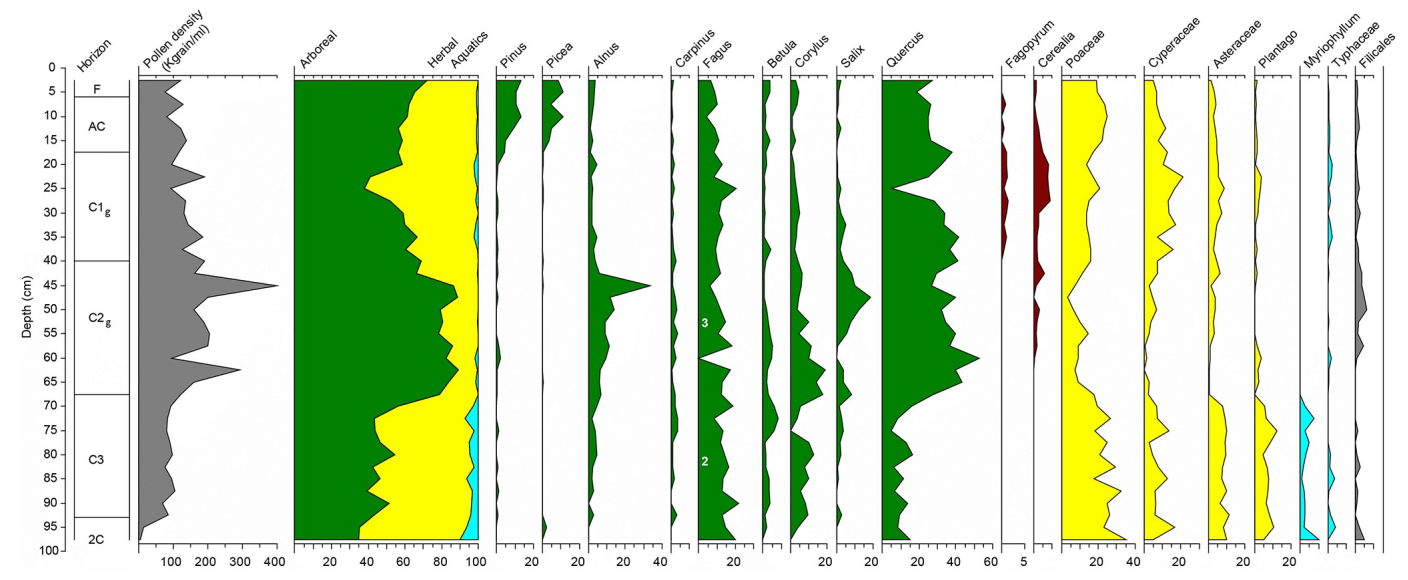

\section{SOILD}

doi:10.5194/soil-2015-82

\section{Natural versus anthropogenic genesis of mardels on the Gutland plateau}

J. M. van Mourik et al.

\section{Title Page}

Abstract

Introduction

Conclusions

References

Tables

Figures

14

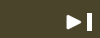

Figure 9. Pollen diagram Michelbouch.

Close

Full Screen / Esc

Printer-friendly Version

Interactive Discussion 


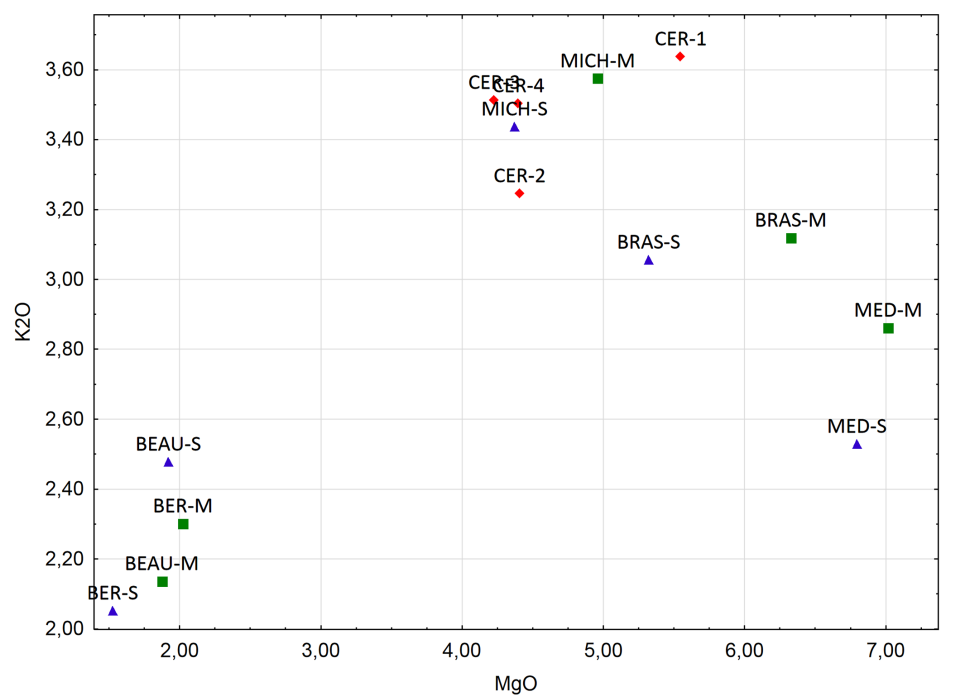

\section{SOILD}

doi:10.5194/soil-2015-82

\section{Natural versus anthropogenic genesis of mardels on the Gutland plateau}

\section{J. M. van Mourik et al.}

\section{Title Page}

Abstract

Introduction

Conclusions References

Tables

Figures

14

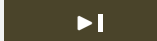

Figure 10. $\mathrm{SiO}_{2} / \mathrm{Al}_{2} \mathrm{O}_{3}$ plot of the 14 samples.

Full Screen / Esc

Printer-friendly Version

Interactive Discussion 


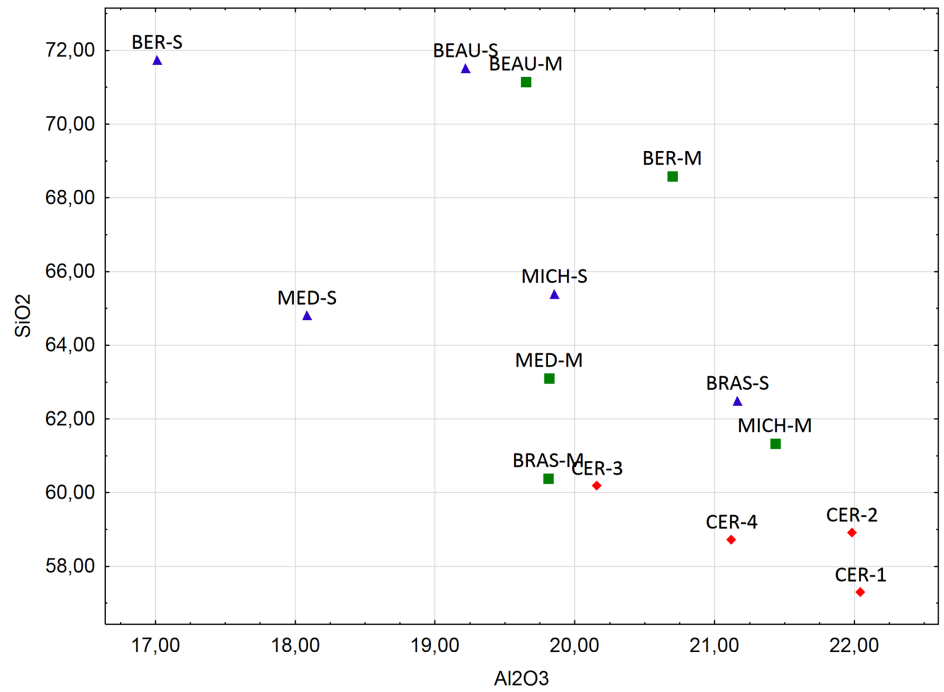

\section{SOILD}

doi:10.5194/soil-2015-82

\section{Natural versus anthropogenic genesis of mardels on the Gutland plateau}

J. M. van Mourik et al.

Title Page

Abstract

Introduction

Conclusions References

Tables

Figures

14

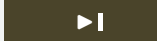

Figure 11. $\mathrm{K}_{2} \mathrm{O} / \mathrm{MgO}$ plot of the 14 samples.

Full Screen / Esc

Printer-friendly Version

Interactive Discussion 


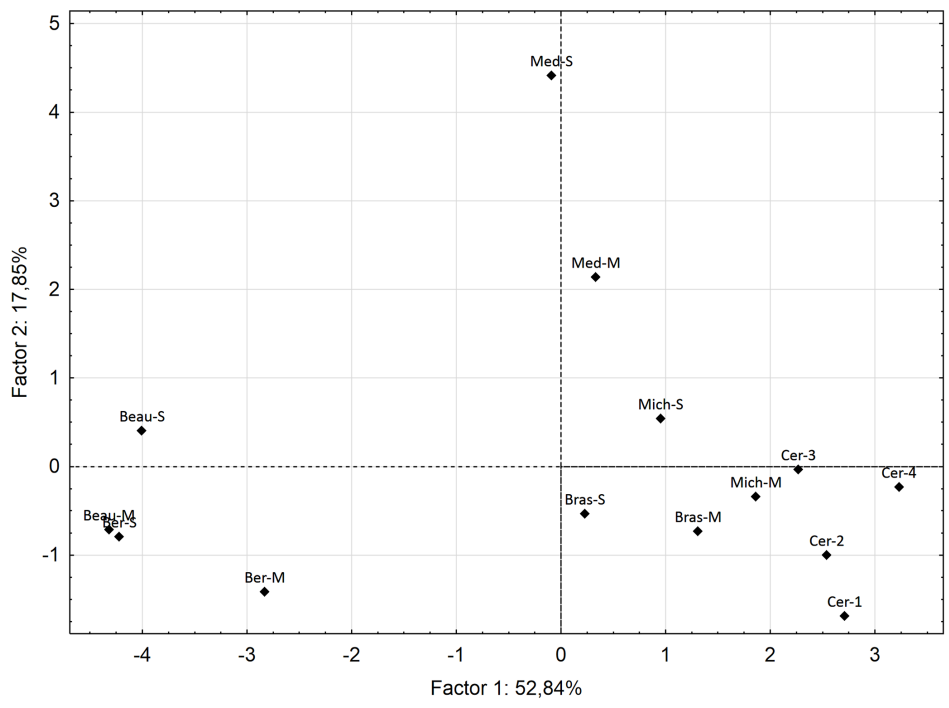

\section{SOILD}

doi:10.5194/soil-2015-82

\section{Natural versus anthropogenic genesis of mardels on the Gutland plateau}

J. M. van Mourik et al.

Title Page

Abstract

Introduction

Conclusions

References

Tables

Figures

14

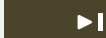

Figure 12. Score plot of principal components 1 and 2 (PC1 vs. PC2), representing 53 and $18 \%$ of total variance.

Full Screen / Esc

Printer-friendly Version

Interactive Discussion 


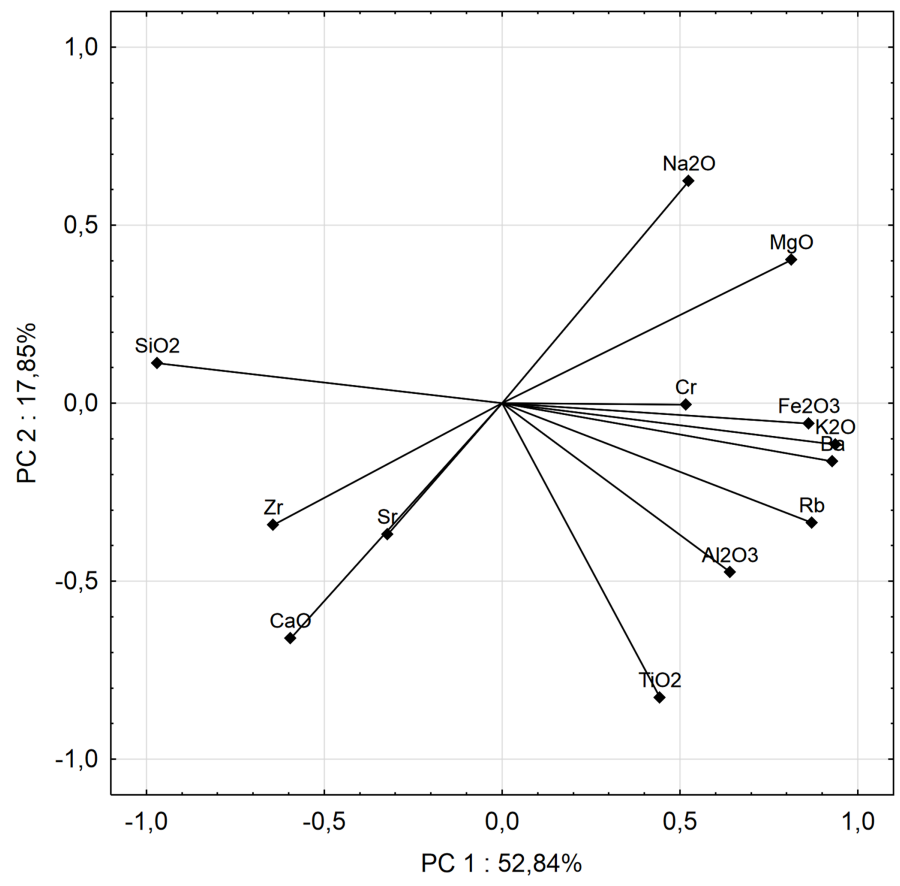

\section{SOILD}

doi:10.5194/soil-2015-82

\section{Natural versus anthropogenic genesis of mardels on the Gutland plateau}

J. M. van Mourik et al.

\section{Title Page}

Abstract

Introduction

Conclusions

References

Tables

Figures

14

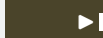

$>$ I

Figure 13. Loading plot of principal components 1 and 2 (PC1 vs. PC2), representing 53 and $18 \%$ of total variance.

\section{Full Screen / Esc}

Printer-friendly Version

Interactive Discussion 


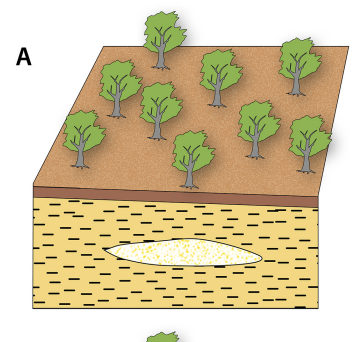

\section{SOILD}

doi:10.5194/soil-2015-82
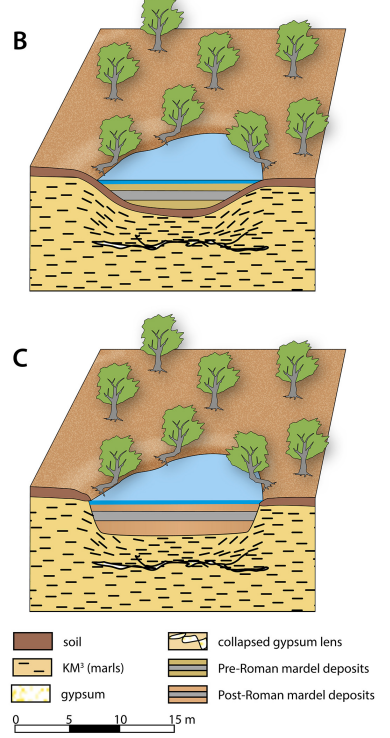

Title Page

Abstract

Introduction

Conclusions

References

Tables

Figures

14

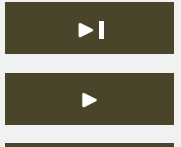

Back

Close

Figure 14. The development of mardels on the Steinmergelkeuper. (a) Initial landscape on the Steinmergelkeuper $\left(\mathrm{km}^{3}\right)$, with a subsurface gypsum lens, (b) the development of a subsidence basis, caused by dissolution of the gypsum lens, filled with pre-Roman clayey colluvium, burying the descended palaeosol, (c) mardel after Roam clay excavation, filled with post-Roman clayey colluvium, burying the quarry floor.

Printer-friendly Version

Interactive Discussion 